\title{
$\delta$ and $\mu$ Enkephalins Inhibit Spontaneous GABA-mediated IPSCs via a Cyclic AMP-Independent Mechanism in the Rat Hippocampus
}

\author{
Carl R. Lupica \\ Department of Pharmacology, University of Colorado Health Sciences Center, Denver, Colorado 80262
}

The effects of enkephalins selective for $\delta$ and $\mu$ opioid receptors on inhibitory postsynaptic currents (IPSCs) mediated by GABA were studied in chloride-loaded CA1 pyramidal neurons in adult rat hippocampal slices. The $\mu$ agonist DAMGO $(0.1 \mu \mathrm{M})$ significantly reduced the amplitudes of evoked monosynaptic IPSCs, recorded following the antagonism of excitatory glutamate receptors, and this effect was reversed by the $\mu$ antagonist CTOP $(1 \mu \mathrm{M})$. The selective $\delta$ receptor agonists DPDPE and D-Ala ${ }^{2}$-deltorphin II (both 0.1 $0.5 \mu \mathrm{M}$ ) had no effect on these evoked currents. In contrast, the frequency of tetrodotoxin-resistant spontaneous miniature GABA-mediated currents (m-IPSCs) was significantly reduced by both DPDPE $(0.1-0.5 \mu \mathrm{M})$ and DAMGO (0.1-0.5 $\mu \mathrm{M})$, while the amplitudes of these events were unaltered. These effects were reversed by the selective $\delta$ antagonist ICI 174,864 (1 $\mu \mathrm{M})$ and the selective $\mu$ antagonist CTOP (1 $\mu \mathrm{M})$, respectively. To investigate the mechanisms of this $\mu$ and $\delta$ receptor-mediated modulation of GABA release, and the possible involvement of a cAMP-sensitive $\mathrm{K}^{+}$conductance, spontaneous action potential-dependent IPSCs (s-IPSCs) were measured following pretreatment with 8-bromo-cAMP (8-Br-cAMP). 8-Br-cAMP (250 $\mu \mathrm{M})$ had no effect alone on the amplitude or frequency of S-IPSCs, nor did it alter the inhibitory effects of the $\delta$ and $\mu$ agonists. These results indicate that $\delta$ and $\mu$ opioid receptor activation inhibits spontaneous GABA release, independently of CAMP, through direct actions at inhibitory nerve terminals, and that $\delta$ opioids inhibit spontaneous but not evoked GABA release in the hippocampus.

[Key words: miniature IPSCs, opioid, interneuron, release, electrophysiology, whole cell, cAMPJ

Opioid peptides inhibit neural activity in most regions of the CNS by reducing neurotransmitter release and hyperpolarizing neural membranes. In contrast to the inhibition of neural activity seen in most brain regions, opioids excite some classes of neurons, for example, the dopaminergic cells of the ventral tegmental area (Johnson and North, 1992) and pyramidal neurons in the hippocampus (Zieglgansberger et al., 1979; Dunwiddie et al., 1980; Dingledine, 1981; Lupica et al., 1992a). Rather than being generated by direct interaction with receptors on these postsynaptic cells, this opioid-mediated excitation is due to a

\footnotetext{
Received May 13, 1994; revised July 1, 1994; accepted July 14, 1994.

This work was supported by Grant DA 07725 from the National Institutes of Health, U.S. Public Health Service.

Correspondence should be addressed to Carl R. Lupica, Ph.D., Department of Pharmacology, Box C-236, University of Colorado Health Sciences Center, 4200 East 9th Avenue, Denver, CO 80262.

Copyright (C) 1995 Society for Neuroscience $0270-6474 / 95 / 150737-13 \$ 05.00 / 0$
}

reduction of $\mathrm{GABA}$ release from local circuit neurons (interneurons). In the hippocampus this conclusion receives support from studies showing that interneuron firing rates are diminished in the presence of opioids, as are GABA-mediated inhibitory postsynaptic potentials/currents (IPSP/Cs) recorded from pyramidal neurons (Zieglgansberger et al., 1979; Lee et al., 1980; Nicoll et al., 1980; Pang and Rose, 1989; Lupica et al., 1992a).

The cellular mechanism of these opioid actions on hippocampal interncurons is not well understood. Opioids may indirectly decrease GABA release via a reduction in interneuron excitability following somatic membrane hyperpolarization. Evidence for this hypothesis is obtained from studies showing that opioid receptors in the hippocampus activate an inwardly rectifying $\mathrm{K}^{+}$conductance that is sensitive to $\mathrm{K}^{+}$channel blockers such as barium and cesium. This $\mathrm{K}^{+}$channel hyperpolarizes hippocampal interneurons, and neurons in other brain regions (Williams et al., 1982; North et al., 1987; Madison and Nicoll, 1988; Wimpey and Chavkin, 1991, 1992). In addition to this $\mathrm{K}^{+}$channel, a voltage-dependent $\mathrm{K}^{+}$conductance that is activated by opioids has been identified in hippocampal interneurons. The opioid activation of this channel is blocked by cyclic adenosine-5'-monophosphate (cAMP) analogs, and, since this channel is active only at depolarized potentials, it has been suggested that it may be important for shaping interneuron firing patterns (Wimpey and Chavkin, 1991, 1992). It is likely that the activation of one or both of these $\mathrm{K}^{+}$channels by opioids would limit GABA release that is dependent upon action potentials. However, these channels are probably not involved in the opioid inhibition of spontaneous GABA release that occurs when action potentials are eliminated by the inclusion of tetrodotoxin (TTX) in the extracellular recording medium (Cohen et al., 1992; Capogna et al., 1993; Rekling, 1993).

There is strong evidence that opioid receptor heterogeneity exists throughout the hippocampus, and that $\delta$ and $\mu$ opioid receptors are found in moderate to high concentrations in area CAl (Crain et al., 1986; Herkenham and McLean, 1988; Sharif and Hughes, 1989). Furthermore, each of these receptor subtypes has been proposed to mediate the inhibition of GABA release in this structure (Bostock et al., 1984; Lupica and Dunwiddie, 1991; Lupica et al., 1992a). However, most studies of opioid effects in the hippocampus have utilized agonists that are either nonselective for these opioid receptor subtypes, or selective for only $\mu$ receptors. In the studies in which selective $\mu$ and $\delta$ enkephalins were directly compared, it was found that these receptor subtypes modulated evoked GABA release differently. Specifically, only $\mu$, and not $\delta$, receptor agonists were observed to reduce stimulus-evoked GABA release (Lupica and Dunwiddic, 1991; Lupica et al., 1992a; Capogna et al., 1993; Watson and Lanthorn, 1993). However, despite this apparent 
absence of $\delta$ enkephalin effects on evoked GABA release, both $\mu$ and $\delta$ agonists were found to decrease spontaneous, action potential-dependent IPSPs (Lupica et al., 1992a).

The present investigation utilized whole-cell patch-clamp recording from pyramidal neurons to address several questions raised by the aforementioned studies. First, are both $\mu$ and $\delta$ receptors present on inhibitory nerve terminals in the hippocampus? Second, is it possible that the lack of $\delta$ opioid actions on evoked GABA release was due to the absence of $\delta$ receptors on interneuron nerve terminals? Third, is the voltage-dependent $\mathrm{K}^{*}$ conductance that is activated by opioids and blocked by cAMP functionally significant, and are the inhibitory actions of $\mu$ or $\delta$ opioids on GABA release in the hippocampus due to alterations in cAMP levels?

\section{Materials and Methods}

Preparation. Experiments were performed using 150-200 gm male Sprague-Dawley rats obtained from Sasco (Omaha, NE). The animals were killed by decapitation, the brains were rapidly removed and immediately placed in icc-cold artificial cerebral spinal fluid (aCSF), and the hippocampus was dissected free of the surrounding tissue. The aCSF consisted of (in mu) NaCl, $126 ; \mathrm{KCl}, 3.0 ; \mathrm{MgCl}_{2}, 1.5 ; \mathrm{CaCl}_{2}, 2.4 ; \mathrm{NaH}_{2} \mathrm{PO}_{4}$, 1.2; glucose, 11.0; and $\mathrm{NaHCO}_{3}, 25.9$; and was aerated with $95 \% \mathrm{O}_{2}$ and $5 \% \mathrm{CO}_{2}$. Transverse slices (400 $\mu \mathrm{m}$ nominal thickness) were taken from the middle portion of the hippocampus using a Sorvall tissue chopper (Newtown, CT). The slices were immediately placed in icecold aCSF until transferred to a holding chamber containing oxygenated aCSF maintained at $33 \pm 1^{\circ} \mathrm{C}$. The slices were held at the liquid medium-gas interface in this chamber for at least $60 \mathrm{~min}$ before being used for recording. When testing procedures were begun, a slice was submerged in a recording chamber with a volume of approximately $0.5 \mathrm{ml}$, and a constant flow of fresh, oxygenated, preheated medium was initiated at a rate of $2 \mathrm{ml} / \mathrm{min}$.

Electrophysiology. Whole-cell patch-clamp recordings from pyramidal neurons were obtained using an Axoclamp-2A amplifier (Axon Instruments, Burlingame, CA). Whole-cell pipettes were pulled from borosilicate, Omega-dot, thick-walled capillary tubing $(0.75 \mathrm{~mm}$ i.d., 1.5 mm o.d.; Sutter Instrument Co., Novato, CA) and typically had resistances of 4-6 M $\Omega$ when filled with the following solution (in $\mathrm{mM}$ ): $\mathrm{CsCl}$, 130; EGTA, 1.0; $\mathrm{CaCl}_{2}, 0.5 ; \mathrm{MgCl}_{2}, 2.0$; ATP:di-Na ${ }^{+}, 2.0$; HEPES: hemi- $\mathrm{Na}^{+}, 10 ; \mathrm{pH}$ adjusted to $7.2-7.4$ with $\mathrm{CsOH}$. The recording pipettes also contained the quaternary lidocaine derivative lidocaine $N$-ethyl bromide (QX-314; $3.0 \mathrm{~mm}$ ) to block action potential discharge. The inclusion of chloride in the recording pipettes reversed the polarity of the GABA-mediated currents from outward to inward, and enhanced their detection by increasing the driving force on chloride ions. Junction potentials were nulled in the aCSF prior to attempting to form a membranc scal. Neurons were detected while slowly passing the recording pipette through the CA1 pyramidal cell layer, as described previously (Lupica et al., 1992a,b). After the formation of a seal $\left(>10^{\circ} \Omega\right)$ between the pipette tip and the neuronal membrane, the membrane patch was ruptured and neurons were voltage clamped at -60 to $-90 \mathrm{mV}$ using the continuous single-electrode voltage-clamp mode. Series resistance was compensated $70-90 \%$, and cells were rejected if the background recording noise increased during the experiment. Spontaneous currents were stored on an FM tape recorder for subsequent digitization and analysis. Evoked and spontaneous membrane currents were amplified $100 \times$, filtered at $1-3 \mathrm{kHz}$, and digitized at $4 \mathrm{kHz}$ using either a Data Translation DT2801 A or an R.C. Electronics ISC-16 analog-to-digital card, residing in an AT series personal computer.

Off-line analysis of spontaneous currents was performed with a commercially available computer software package (Strathclyde, CDR, Dagan Corp., Minneapolis, MN). Spontaneous IPSC (no TTX) and miniature IPSC (recorded in TTX) amplitudes, frequencies, and interevent intervals were determined from $120 \mathrm{sec}$ epochs using a software event detector. This detector was set to discriminate events longer than $3 \mathrm{msec}$ in duration, and the amplitude threshold was set just above the maximum background recording noise. These criteria were set for each experiment and were kept constant throughout each of the recording epochs (i.e., the detector was the same for control, drug, and washout periods). If the background noise increased during one of the recording epochs, the cell was omitted from further analysis. Each detected event was visually inspected to ensure that no obvious false IPSCs were included in the data sets. The amplitude and frequency data obtained from each cell were expressed in the form of cumulative probability density distributions, with each distribution normalized to a maximal value of 1 . Differences between data obtained in each epoch were evaluated for significance using the Kolmogorov-Smirnov (K-S) statistic, which estimates the probability that two cumulative distributions differ from each other by chance alone (Van Der Kloot, 1991; Cohen et al., 1992). A conservative critical probability value of $p<0.01$ was chosen to determine statistical significance. Each data set contained 350-1500 events. In some cases, exponential, Gaussian, or log-normal curves were fit to the data sets using a curve-fitting computer program (SLIDEWRITE, Advanced Graphics Software, Carlsbad, CA). This program utilizes a nonlinear, iterative algorithm that calculates fit coefficients until the sum of the squared variances of these coefficients is minimized (least squares criterion).

In some experiments GABA-mediated IPSCs were evoked in the presence of APV and DNQX to reduce or eliminate glutamate mediated synaptic transmission. These so-called monosynaptic IPSCs were elicited with a twisted nichrome wire stimulation electrode placed in stratum radiatum, or stratum pyramidale, within approximately $100-200$ $\mu \mathrm{m}$ of the recording pipette. The stimulation pulses were monophasic and $0.1 \mathrm{msec}$ in duration, and typically were $5-30 \mathrm{~V}$ in magnitude. Stimuli were delivered every $30 \mathrm{sec}$. All group data were analyzed for significance using either the Student's $t$ test or an analysis of variance (ANOVA) using a critical probability of $p<0.05$. All group data are reported as mean \pm 1 SEM.

Chemicals. All drugs used in this study were dissolved in deionized $\mathrm{H}_{2} \mathrm{O}$ at $100 \times$ their final bath concentrations and added to the flowing aCSF using calibrated syringe pumps $(20 \mu \mathrm{l} / \mathrm{min}$; Razel Scientific Instruments, Stamford, CT). The membrane-permeable cAMP analog 8-BrcAMP (Sigma, St. Louis, MO) was made fresh daily in deionized $\mathrm{H}_{2} \mathrm{O}$ that had been boiled for $5 \mathrm{~min}$ and then cooled to room temperature to reduce its oxygen content. The $\delta$ receptor agonists DPDPE (DPen $^{2}, P^{-} n^{5}$-enkephalin) and [D-Ala ${ }^{2}$-deltorphin-II (Tyr-D-Ala-Phe-GluVal-Val-Gly- $\mathrm{NH}_{2}$ ), the $\mu$ agonist DAMGO (Tyr-D-Ala ${ }^{2}, N-\mathrm{CH}_{3}-\mathrm{Phe}^{4}, \mathrm{Gly}-$ ol-enkephalin), and the $\mu$ antagonist $\mathrm{Cys}^{2}, \mathrm{Tyr}^{3}, \mathrm{Orn}^{5}, \mathrm{Pen}^{7}$-amide (CTOP) were obtained from Peninsula Laboratories (Belmont, CA). The $\delta$ antagonist $N, N$-diallyl-Tyr-Aib-Aib-Phe-Leu (ICI 174,864) was obtained from Research Biochemicals (Natick, MA). Tetrodotoxin, bicuculline methiodide, and theophylline were obtained from Sigma (St. Louis, MO). QX-314 was obtained from Alomone Labs (Jerusalem, Israel). In all of the experiments D,L-2-amino-5-phosphonovalerate (APV) and 6,7-dinitroquinoxaline-2,3-dione (DNQX; both obtained from Sigma, St. Louis, MO) were included in the aCSF to block glutamatergic NMDA and non-NMDA ionotropic receptors.

\section{Results}

Previous studies from this laboratory have demonstrated that the $\mu$ enkephalin agonist DAMGO could increase EPSP amplitudes secondarily to a reduction in IPSPs recorded from CA1 pyramidal neurons. This $\mu$ receptor effect was in contrast to the $\delta$ enkephalin agonist DPDPE, which increased EPSPs but did not reliably alter evoked inhibitory responses (Lupica et al., 1992a). The absence of $\delta$ agonist actions on IPSPs may have been obscured by the concomitant increase in synaptic excitation that was observed. Other possibilities were that $\delta$ receptor activation reduced an inhibitory GABAergic input at an electrotonically remote compartment of the pyramidal neuron (Dingledine, 1981; Lupica et al., 1992a), or that $\delta$ receptors were simply absent from interneuron nerve terminals in the CAl region of the hippocampus. In the prescnt expcriments, IPSCs were evoked in the presence of the glutamate receptor antagonists DNQX and APV to minimize the possibility that $\delta$-mediated changes in the amplitudes of evoked inhibitory responses were obscured by alterations in slice excitability (Davies and Collingridge, 1989; Lambert et al., 1991). To evaluate the second possibility, that $\delta$ receptors reduced an inhibitory input that was electrotonically remote, evoked IPSCs were recorded from pyramidal neurons loaded with $130 \mathrm{~mm} \mathrm{Cl}^{-}$. This was done in 

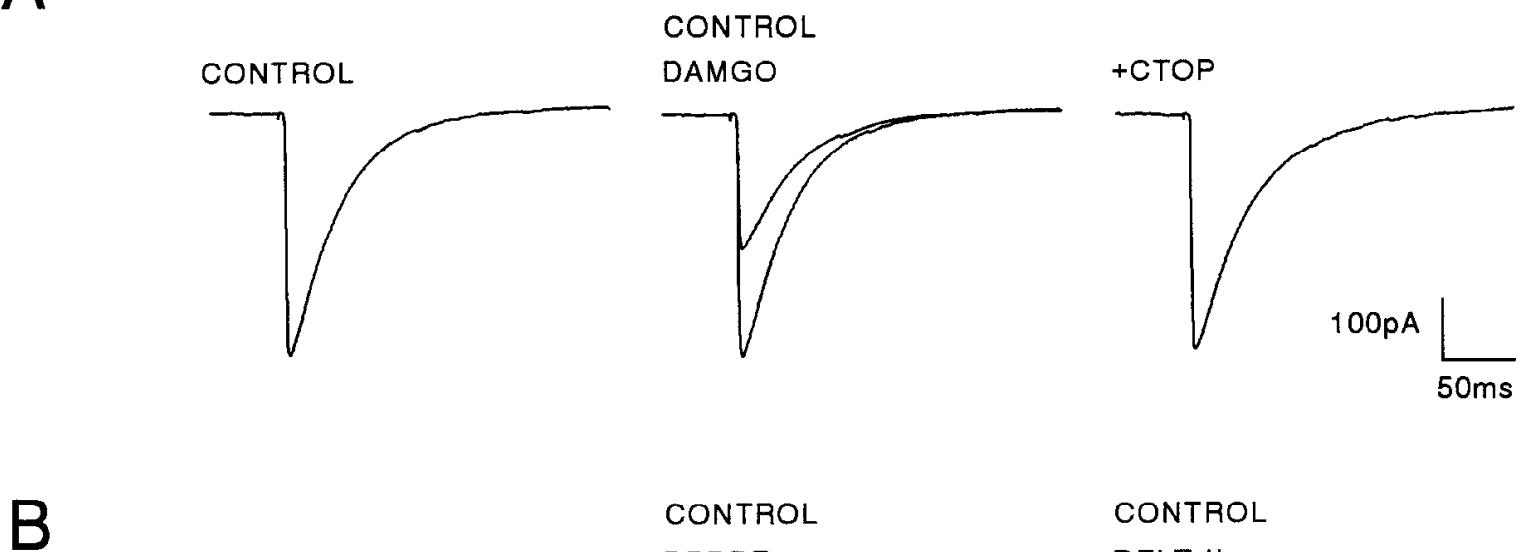

CONTROL DPDPE

CONTROL

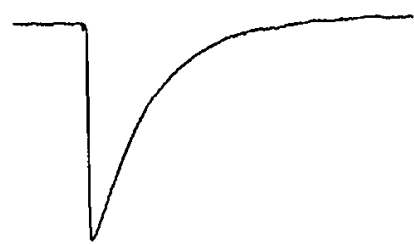

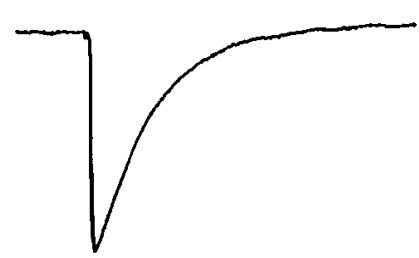

CONTROL

DELT-II

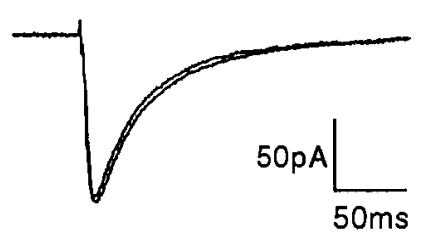

Figure 1. Effects of opioid peptides on evoked IPSCs recorded from chloride-loaded cells. These monosynaptic responses were elicited by direct electrical stimulation of interneurons following pretreatment with the glutamate receptor antagonists APV (40 $\mu \mathrm{M})$ and DNQX (10 $\mu \mathrm{M}) . A$, Effects of the $\mu$ opioid receptor agonist DAMGO $(0.1 \mu \mathrm{M})$ on evoked monosynaptic IPSCs. Superimposed traccs obtained during the control and DAMGO application periods are shown in the center panel. The antagonism of the DAMGO-mediated inhibition by the selective $\mu$ receptor antagonist CTOP $(1 \mu \mathrm{M})$ is shown at right. $B$, Effects of opioid agonists selective for $\delta$ receptors on monosynaptic IPSCs recorded from two different CA1 pyramidal neurons. Shown are the averaged responses prior to DPDPE application and superimposed signal averages obtained before and during agonist application. Neither of the $\delta$ agonists DPDPE or Delt-II (both at $0.1 \mu \mathrm{M}$ ) modified these evoked synaptic responses. All of the cells used in the evoked IPSC experiments were voltage clamped at $-70 \mathrm{mV}$.

an effort to enhance the contribution of this hypothesized remote conductance to the whole-cell evoked current. The third possibility, that $\delta$ receptors are not present on ${ }^{-\cdots}{ }^{-}$itory nerve terminals, was evaluated by measuring $\delta$ agonist effects on miniature IPSCs.

\section{$\mu$ and not $\delta$ opioid receptors reduce evoked monosynaptic IPSCs}

Pyramidal neurons were voltage clamped at $-70 \mathrm{mV}$ and IPSCs were evoked following at least $30 \mathrm{~min}$ pretreatment with the glutamate receptor antagonists DNQX $(10 \mu \mathrm{M})$ and APV (40 $\mu \mathrm{M})$. Electrical stimulation of hippocampal slices in the presence of these antagonists yields a response that is completely blocked by addition of the $\mathrm{GABA}_{\mathrm{A}}$ receptor antagonist bicuculline methiodide and the $\mathrm{GABA}_{\mathrm{B}}$ receptor antagonist phaclofen (Lupica et al., 1992a). These responses thus reflect the direct activation of only GABAergic interneurons, and are therefore referred to as monosynaptic IPSCs. These responses were significantly reduced by the $\mu$ agonist DAMGO $(0.05-0.5 \mu \mathrm{M})$. Overall, DAMGO $(0.1 \mu \mathrm{M})$ decreased these monosynaptic responses to $49 \pm$ $11 \%$ of control $(n=8 ; p<0.05$, paired $t$ test). This effect was completely reversed by washing out the peptide, by bath application of the opioid antagonist naloxone, or by the selective $\mu$ receptor antagonist CTOP $(94 \pm 14 \%$ of control; Fig. $1 A)$. In contrast to this action of the $\mu$ agonist, the $\delta$ agonist DPDPE (0.05-1 $\mu \mathrm{M})$ had no overall effect on evoked monosynaptic IPSCs $(95 \pm 16 \%$ of control; $n=10 ; p>0.05$, paired $t$ test; Fig. $1 B$ ). Another peptide agonist that demonstrates higher affinity and selectivity for $\delta$ opioid receptors, [D-Ala ${ }^{2}$ ]-deltorphin II (DeltII; $0.1 \mu \mathrm{M})$ (Erspamer et al., 1989; Kramer et al., 1993), was also without significant effect on these monosynaptic IPSCs (Fig. $1 B)$. Overall, Delt-II decreased monosynaptic IPSCs to $98 \pm$ $9 \%$ of control ( $n=9 ; p>0.05$, paired $t$ test).

The results of these experiments suggested that $\delta$ opioid agonists had no effect upon the evoked release of GABA measured in chloridc-loadcd cclls. In addition, since these responses were evoked in the absence of glutamatergic synaptic transmission, it seems unlikely that a reduction in evoked IPSC amplitude could be obscured by increases in synaptic excitability. Therefore, the next series of experiments were designed to determine whether $\delta$ opioid receptors were present on inhibitory nerve terminals in area $\mathrm{CAl}$ of the hippocampus.

\section{Characteristics of miniature IPSCS}

Spontaneous IPSCs recorded from pyramidal neurons in the presence of TTX are shown in Figure 2. Hereafter responses obtained in the presence of TTX will be referred to as miniature IPSCs (m-IPSCs), while those obtained in the absence of $\mathrm{Na}^{+}$ channel blockade will be referred to as spontaneous IPSCs (sIPSCs). These m-IPSCs were acquired using whole-cell electrodes containing $130 \mathrm{~mm} \mathrm{CsCl}$, in the presence of DNQX (10 $\mu \mathrm{M})$ and APV $(40 \mu \mathrm{M})$ to block spontaneous EPSC occurrence. Although the spontaneous currents exhibited a great deal of variability among cells, the effect of TTX was to decrease substantially their frequency and average amplitude. An example of these actions upon s-IPSCs can be seen in Figure 2, where TTX $(1 \mu \mathrm{M})$ caused a threefold increase in the average interevent interval (from 59.4 to $184.8 \mathrm{msec}$ ), and a decrease in average IPSC amplitude (from 46.6 to $12.6 \mathrm{pA}$ ). These data indicate that a significant portion of the currents was due to action po- 

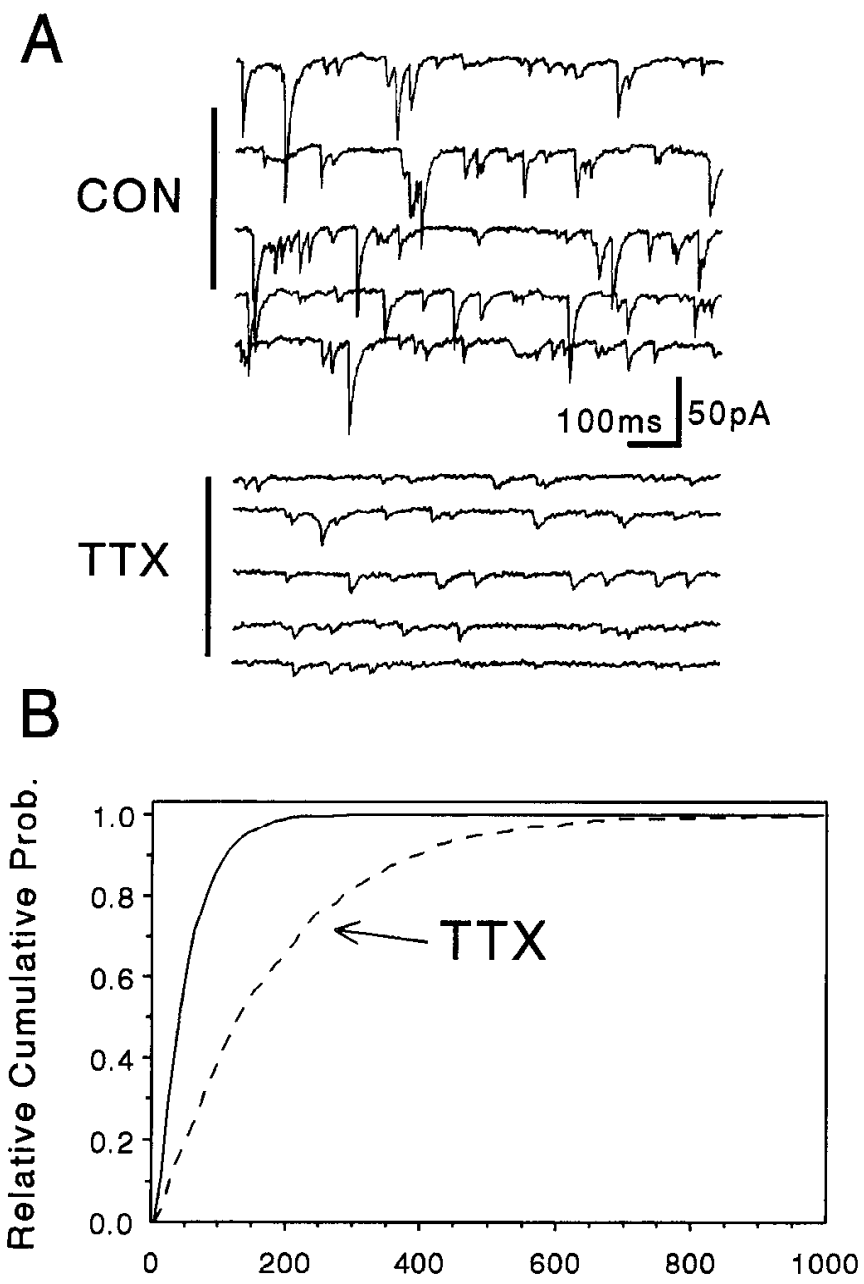

Inter-Event Interval (ms)
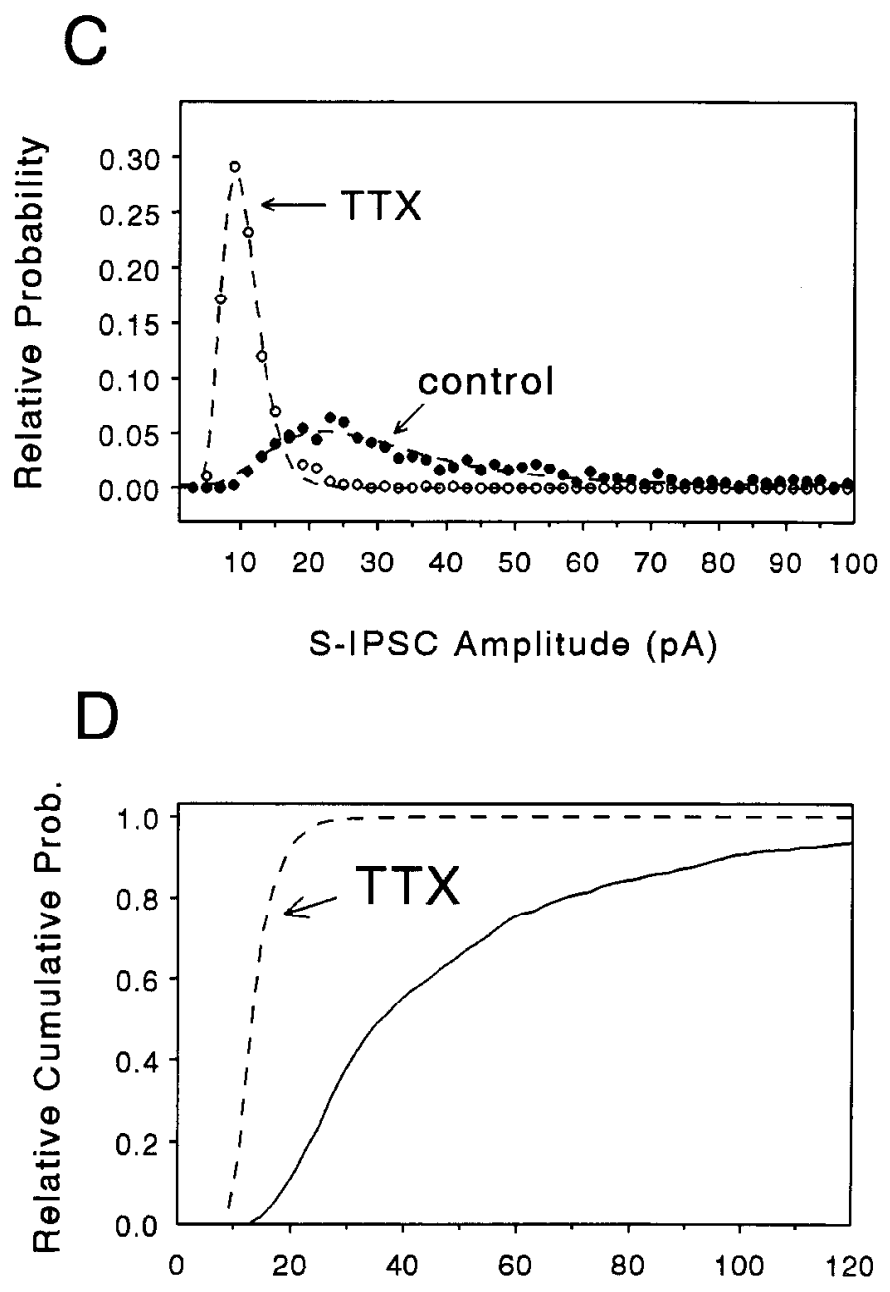

S-IPSC Amplitude (pA)

Figure 2. Effects of voltage-dependent $\mathrm{Na}^{+}$channel blockade on spontaneous inward IPSCs mediated by the release of GABA. This cell was pretreated with glutamate receptor antagonists, as described in Figure 1 , and voltage clamped at $-70 \mathrm{mV}$. $A$, Individual consecutive sweeps of 1 sec duration before $(C O N)$ and at the end of a $55 \mathrm{~min}$ application of tetrodotoxin $(1 \mu \mathrm{M} ; T T X)$. $B$, Cumulative interevent interval histogram of the IPSCs collected during the last $2 \mathrm{~min}$ of the control (solid line) and TTX (dashed line) periods (intervals: control $=58.9 \pm 1.6 \mathrm{msec}, n=715$ events; TTX $=184.6 \pm 6.4 \mathrm{msec}, n=643$ events). $C$, Amplitude histograms of IPSCs obtained during the control and TTX periods. Both distributions represent the proportion of events contained in each $2 \mathrm{pA}$ bin. The actual data are represented by the open and solid symbols. The dashed lines represent log-normal fits to the data using the equation $y=a_{1} \exp \left(-0.5 \ln \left(x / a_{2} / a_{3}\right)^{2}\right)$, where $a_{1}$ is the height of the curvc, $a_{2}$ is the center of the curve, and $a_{3}$ is the standard deviation of the curve. The actual values for the control curve were $a_{1}=0.049, a_{2}=22.14 \mathrm{pA}, a_{3}=$ $0.49 \mathrm{pA}$. The values for the TTX curve are $a_{1}=0.284, a_{2}=9.25 \mathrm{pA}, a_{3}=0.28 \mathrm{pA}$. This shift in amplitude was determined to be significant when thesc same data werc cxpressed in a cumulative amplitude distribution $(D)$ and a Kolmogorov-Smirnov (K-S) test performed $(p<0.0001)$. All data were obtained from the same cell.

tential-dependent GABA release from interneurons. Overall, the frequency of m-IPSCs ranged between 5.4 and $19.3 \mathrm{~Hz}$, and the average was $9.1 \pm 1.2 \mathrm{~Hz}(n=16$ cells). The mean amplitude of these same events ranged between 7.4 and $35.0 \mathrm{pA}$, and the average across all cells was $18.9 \pm 2.3 \mathrm{pA}$, when measured at a holding potential of $-70 \mathrm{mV}$. Figure 3 shows the effects of manipulating the pyramidal neuron membrane potential on the characteristics of m-IPSCs. As this figure demonstrates, the m-IPSC amplitude distribution (Fig. $3 A$ ) and their average amplitudes (Fig. $3 B$ ) varied as a function of the pyramidal neuron membrane potential. Also, the m-IPSCs reversed polarity from inward to outward when the pyramidal neuron membrane potential was clamped near $0 \mathrm{mV}$, as would be predicted from the nearly symmetrical extracellular and intraccllular concentrations of chloride (Fig. $3 B, C$ ). These miniature currents could also be completely, and reversibly eliminated by addition of the $\mathrm{GABA}_{\mathrm{A}}$ receptor antagonist bicuculline methiodide (10 $\mu \mathrm{M} ; n$ = 3; data not shown) (Otis et al., 1991; Lupica et al., 1992a).

\section{$\delta$ and $\mu$ opioid receptors reduce miniature IPSCS}

The effects of the $\delta$ receptor-selective agonist DPDPE on m-IPSCs are illustrated in Figure 4. Addition of DPDPE $(0.1 \mu \mathrm{M})$ to the superfusion medium following a $100 \mathrm{~min}$ pretreatment of the hippocampal slice with TTX $(1 \mu \mathrm{M})$ and the selective $\mu$ receptor antagonist CTOP $(1 \mu \mathrm{M})$ caused a significant decrease in the frequency (Fig. $4 A, B$ ) and a corresponding increase in the interevent interval (Fig. 4C) of $\mathrm{m}$-IPSCs in this cell. These alterations were reversed by subsequent addition of the selective $\delta$ opioid reccptor antagonist ICI $174,864(1 \mu \mathrm{M})$. In contrast to the prominent depression of $\mathrm{m}$-IPSC frequency by DPDPE, 

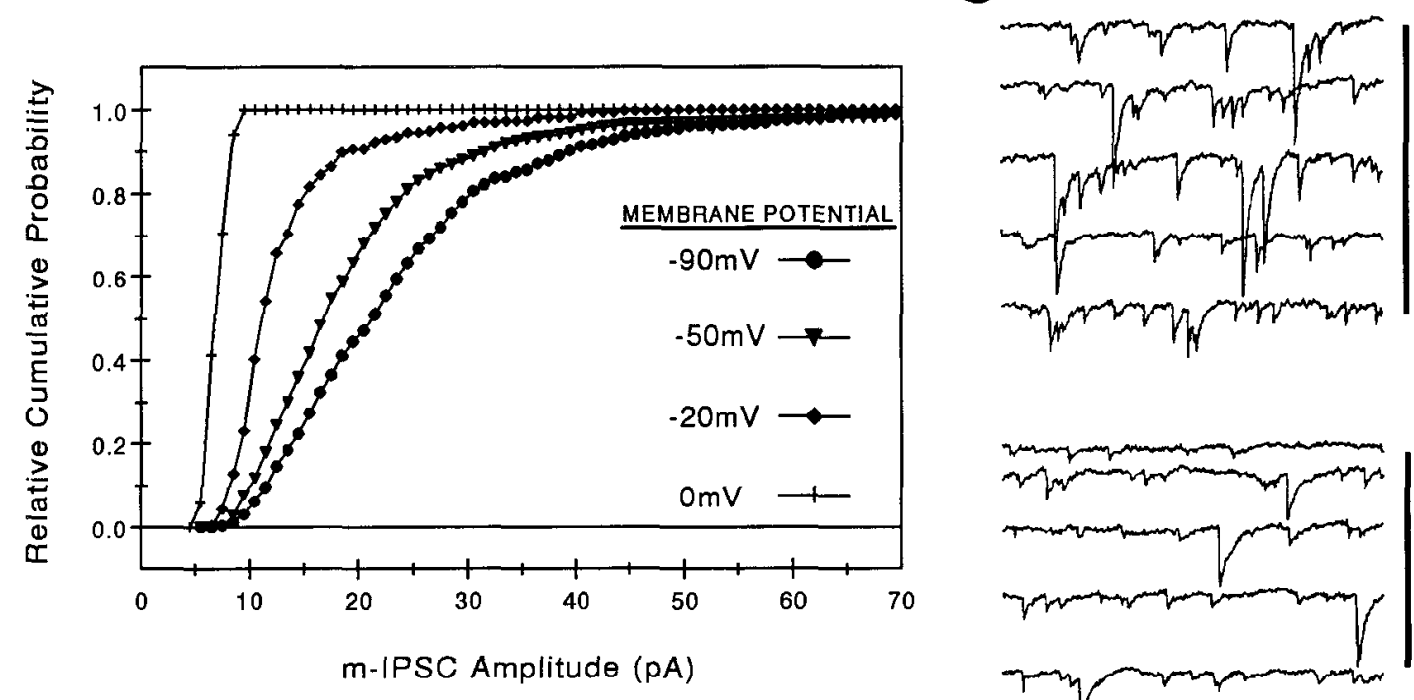

$-90 \mathrm{mV}$

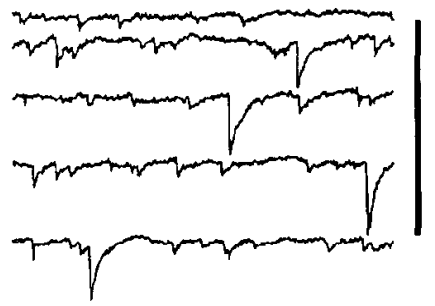

$-20 \mathrm{mV}$

B
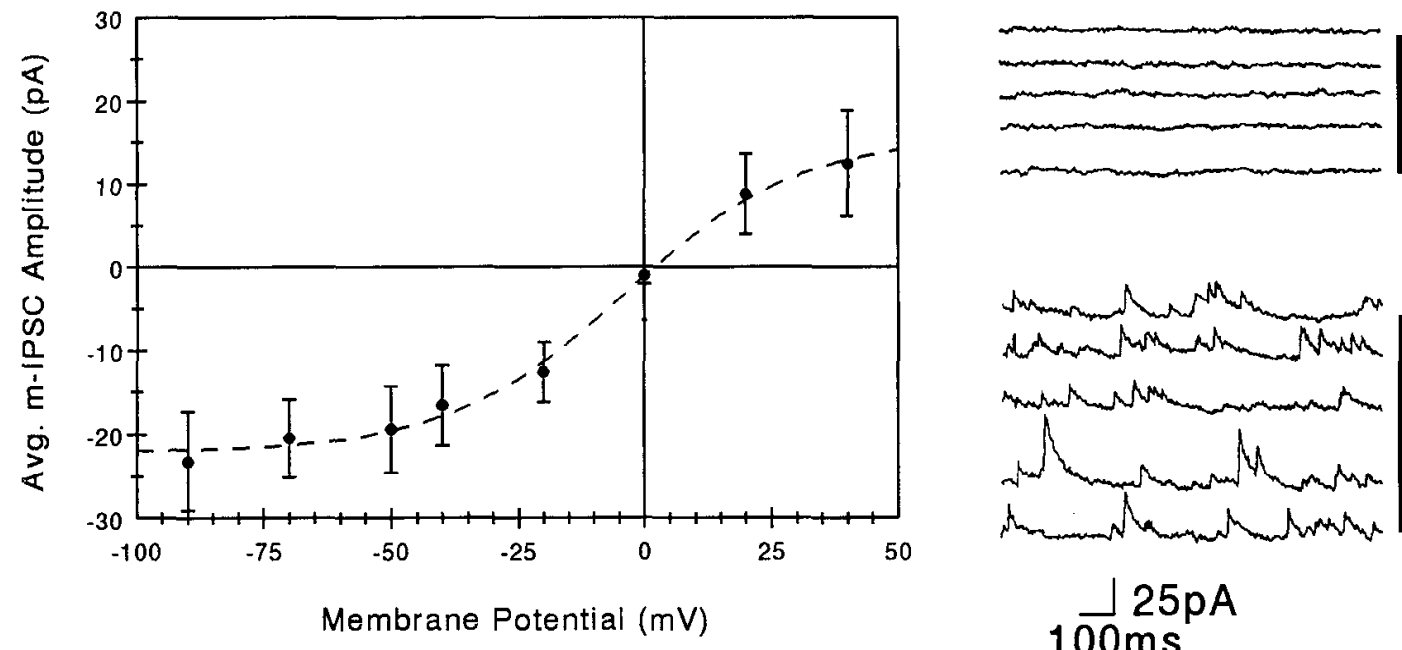

OmV

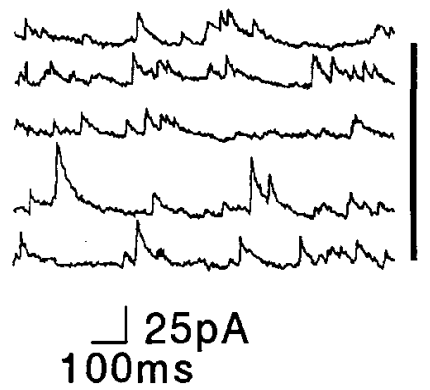

$+40 \mathrm{mV}$

Figure 3. Effects of manipulating membrane potential on m-IPSC amplitude and polarity. $A$, A family of cumulative amplitude distributions illustrating a reduction in m-IPSC amplitude as the reversal potential for $\mathrm{Cl}^{-}\left(E_{\mathrm{u}}\right)$ is approached. Each of these curves was significantly different, as determined by the K-S test $(p<0.0001)$. $B$, Average $\mathrm{m}$-IPSC amplitude plotted as a function of membrane potential. The dashed line represents a nonlinear sigmoidal fit to the averaged data $\left(r^{2}=0.99\right)$; the predicted reversal of the m-IPSCs using this fit was $0.3 \mathrm{mV}$. The number of events averaged for each point was as follows: $-90 \mathrm{mV}, 654 ;-70 \mathrm{mV}, 485 ;-50 \mathrm{mV}, 563 ;-40 \mathrm{mV}, 489 ;-20 \mathrm{mV}, 257 ; 0 \mathrm{mV}, 17 ; 20 \mathrm{mV}, 368 ; 40$ $\mathrm{mV}, 615$. $C$, Representative $1 \mathrm{sec}$ sweeps at the indicated holding potentials, obtained from the same data sets as those in $A$ and $B$. Note the absence of inward currents during the 5 consecutive seconds obtained at $0 \mathrm{mV}$, and the reversal of the m-IPSCs at $40 \mathrm{mV}$. All data obtained from the same cell.

there was no significant effect of this $\delta$ agonist on the amplitudes of these events, as evidenced by the lack of changes in the cumulative amplitude histogram ( $p>0.01$, K-S test; Fig. $4 E$ ). Analysis of the decay of the averaged $m$-IPSCs revealed that this parameter was constant throughout the cxperiment (monoexponential time constants $\tau_{\text {control }}=11.6 \mathrm{msec}, n=500$ events; $\tau_{\text {DPDPE }}=11.4 \mathrm{msec}, n=795$ events; Fig. $4 D$ ). An effect similar to that of DPDPE was also observed with another $\delta$ enkephalin agonist, Delt-II ( $0.1 \mu \mathrm{M} ; n=4$; data not shown). A summary of the inhibitory effects of DPDPE on m-IPSC interevent intervals and amplitudes is shown in Figure 6. Overall, the $\delta$ enkephalin agonist DPDPE increased the average interevent interval of the m-IPSCs from $118.2 \pm 18.4 \mathrm{msec}$ to $224.5 \pm 29.0 \mathrm{msec}$, which represents an increase of $190 \pm 24 \%$ of control ( $n=16$ cells). This effect reversed upon washing or application of ICI 174,864 or naloxone $(5 \mu \mathrm{M})$ to $110 \pm 13 \%$ of control. There was no overall effect of DPDPE on average m-IPSC amplitude $(98 \pm$ $5 \%$ of control; $n=16$ ).

The effects of the selective $\mu$ enkephalin agonist DAMGO were similar to those of DPDPE. As Figure 5 illustrates for a single cell, DAMGO $(0.1 \mu \mathrm{M})$ caused a significant increase in the mean interevent interval from $68.9 \mathrm{msec}$ to $161.3 \mathrm{msec}$ (Fig. $5 A, B)$. This action was reversed by addition of the selective $\mu$ antagonist CTOP ( $1 \mu \mathrm{M}$; mean interevent interval $=75.7 \mathrm{msec})$. An exponential fit to the interevent interval data demonstrates that the release of GABA underlying the m-IPSCs was random 


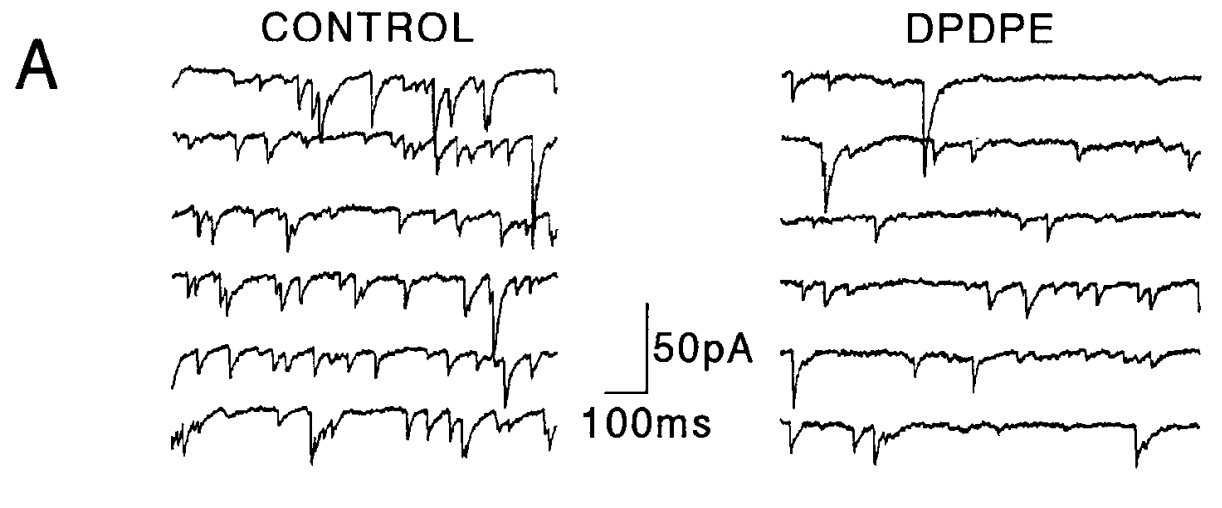

ICl 174,864

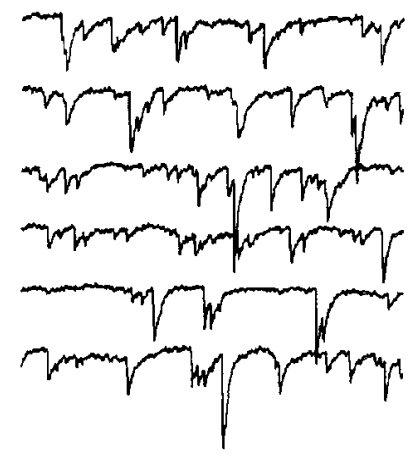

B
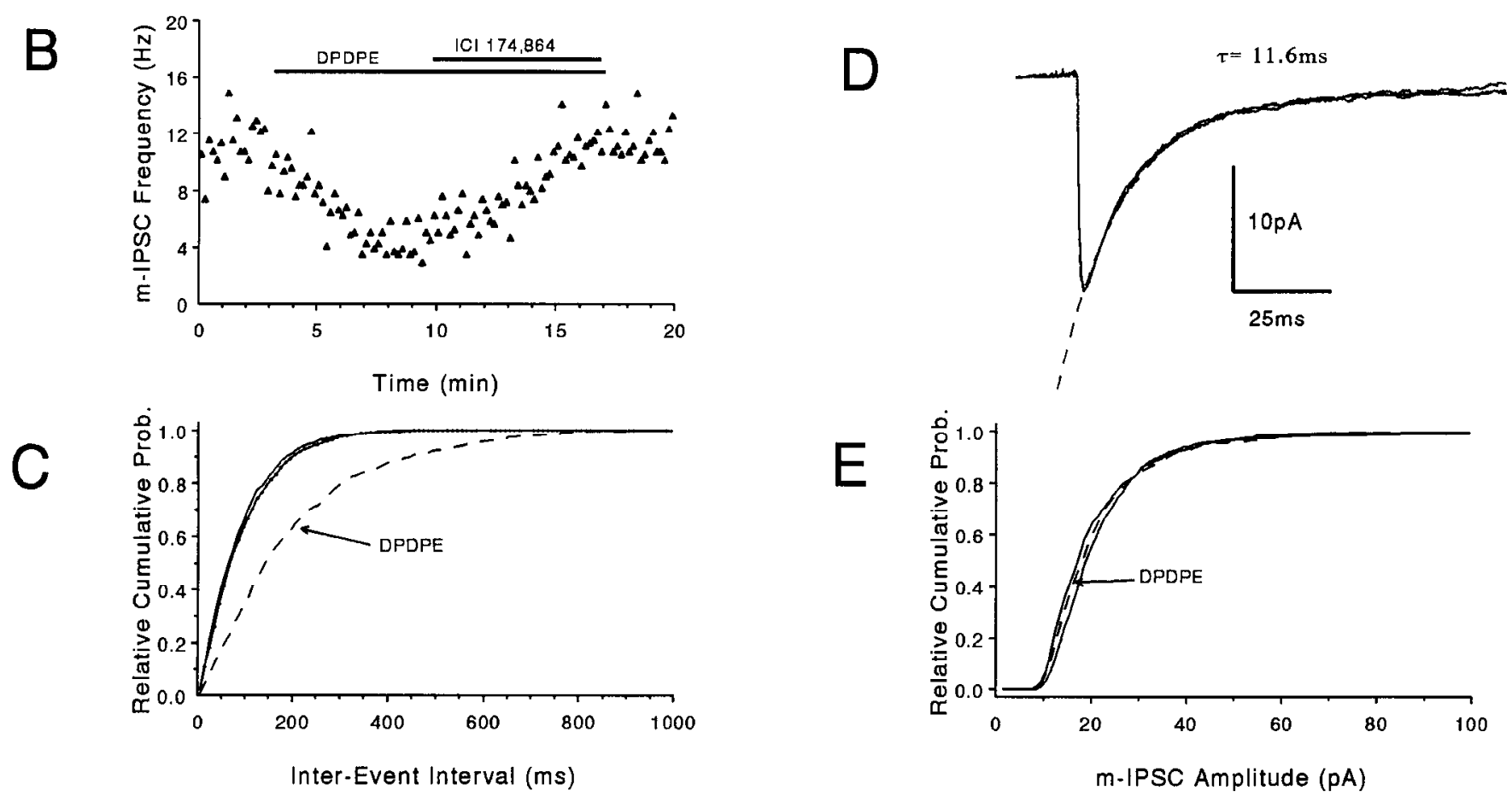

Figure 4. Effects of the selective $\delta$ opioid receptor agonist DPDPE $(0.1 \mu \mathrm{M})$ on m-IPSCs obtained from a cell that was pretreated with DNQX, APV, TTX, and the selective $\mu$ antagonist CTOP $(1 \mu \mathrm{M}) . A$, Consecutive raw traces $(1 \mathrm{sec}$ each) obtained prior to and during DPDPE application. The cffect of DPDPE on m-IPSCs was reversed by the sclective $\delta$ receptor antagonist ICI 174,864 (1 $\mu \mathrm{M})$. $B$, Temporal record of the reduction of $\mathrm{m}$-IPSC frequency (events/sec $=\mathrm{Hz}$ ) by DPDPE, and its reversal by ICI 174,864. Each data point represents the m-IPSC frequency averaged over $10 \mathrm{sec}$ bins. $C$, Cumulative interevent interval distribution indicating that DPDPE increased the interval between consecutive m-IPSCs (interval: control $=90.6 \pm 2.6 \mathrm{msec}, n=823$ events; DPDPE $=200.6 \pm 7.1 \mathrm{msec}, n=483$ events; ICI $174,864=96.8 \pm 2.8 \mathrm{msec}, n=809$ events). Ihe $\mathrm{K}-\mathrm{S}$ statistic revealed that this shift was significant $(p<0.0001)$. $D$, Superimposed averages of all m-IPSCs obtained during control and DPDPE recording epochs. The dashed line represents a monoexponential fit to the control trace using the equation $y=a_{1} \exp \left(-x / a_{2}\right)$. Note the similar amplitudes of both averages, and the similar decay rates. $E$, Cumulative amplitude distributions of m-IPSCs before and during DPDPE application (dashed line), and during perfusion with ICI 174,864. The distributions were not significantly different when analyzed with the K-S statistic ( $p>$ $0.01)$.

under both conditions (Fig. $5 B$; Fatt and Katz, 1952). Also, as the averaged $m$-IPSCs and the cumulative amplitude histogram illustrate (Fig. $5 D, E$ ), there was no significant effect of DAMGO on $\mathrm{m}$-IPSC amplitudes. Once again, the monoexponential decay time constant of the averaged $m$-IPSC remained constant throughout the experiment $\left(\tau_{\text {conirol }}=13.3 \mathrm{msec}, n=807\right.$ events; $\tau_{\text {DAMGO }}=13.6$ msec, $n=736$ events). A summary of the effects of DAMGO on m-IPSCs (Fig. 6) indicated that this $\mu$ agonist increased the average interevent interval from $109.0 \pm 21.6$ msec to $239.4 \pm 54.6 \mathrm{msec}$, which represents an increase of 220 $\pm 50 \%$ of control ( $n=8$ cells). The effect of DAMGO was reversed by washing, or by application of the antagonists CTOP or naloxone $(5 \mu \mathrm{M})$, to $135 \pm 24 \%$ of control. DAMGO also had no overall significant effect on average m-IPSC amplitudes in these same cells (103 $\pm 9 \%$ of control).

\section{Absence of cAMP effects on spontaneous $G A B A$ release}

Several studies have shown that opioid agonists can inhibit the formation of cAMP in brain slices (De Vries et al., 1989; Heijna et al., 1989; Fleming et al., 1992; Schoffelmeer et al., 1992). Also, a recent report has demonstrated that the activation of a voltage-dependent $\mathrm{K}^{+}$conductance in acutely dissociated hip- 

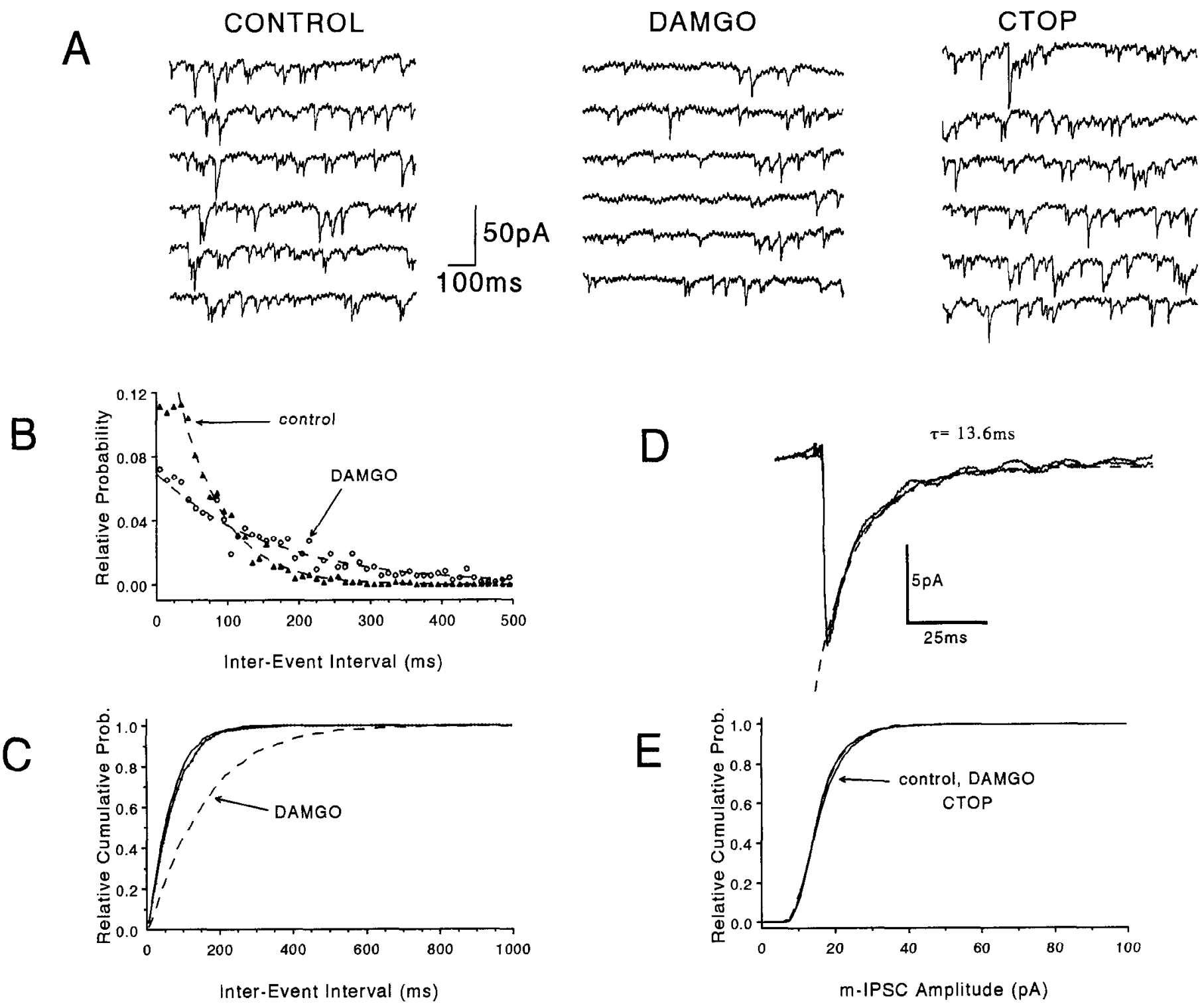

Figure 5. Effects of the selective $\mu$ agonist DAMGO $(0.1 \mu \mathrm{M})$ on $\mathrm{m}$-IPSCs. $A$, Consecutive 1 sec traces obtained during the respective recording epochs. $B$, Noncumulative interevent interval histogram depicting control data (solid triangles) and data obtained during the application of DAMGO (open circles). The dashed lines represent monoexponential fits to the data using the equation $y=a_{1} \exp \left(-x / a_{2}\right)$. The enkephalin shifted the average interevent interval from $68.9 \pm 1.9 \mathrm{msec}(n=807$ events) to $161.3 \pm 5.4 \mathrm{msec}(n=736 \mathrm{events})$, and this effect was largely reversed by CTOP ( 1 $\mu \mathrm{M}$; interevent interval $=75.7 \pm 2.1 \mathrm{msec}$ ). $C$, Cumulative interevent interval distribution using the same data as that in $B$. A statistical analysis of these data indicated that the increase in the intervals between $\mathrm{m}$-IPSCs was significant (K-S statistic, $p<0.0001)$. $D$, Superimposed averages of all m-IPSCs observed during control and DAMGO recording epochs. The dashed line represents a monoexponential fit to the control average. Note the similarity in average $\mathrm{m}$-IPSC amplitude and decay during control and drug periods. $E$, Cumulative amplitude distribution curves generated from data obtained from this cell. The K-S statistic indicated that there was no change in m-IPSC amplitude from control during DAMGO or CTOP application $(p>0.01)$.

pocampal interneurons by $\mu$ opioids could be blocked by pretreatment with the cAMP analog 8-Br-cAMP $(250 \mu \mathrm{M})$ (Wimpey and Chavkin, 1991, 1992). To evaluate the possible involvement of CAMP in the opioid modulation of spontaneous GABA release, and whether this opioid-sensitive voltage-dependent $\mathrm{K}^{+}$ channcl plays a rolc in this process, the actions of $\delta$ and $\mu$ enkephalin agonists were tested following pretreatment with a membrane-permeable analog of cAMP, 8-Br-cAMP. It was hypothesized that since this opioid-sensitive current was voltage dependent, its activation might alter spontaneous, action potential-dependent GABA release (s-IPSCs). Therefore, s-IPSCs were recorded following DNQX $(10 \mu \mathrm{M})$ and APV $(40 \mu \mathrm{M})$ pre- treatment in the absence of TTX. As Figure 7 shows for a single cell under control conditions, the addition of DPDPE $(0.2 \mu \mathrm{M})$ to the superfusion medium caused a large decrease in s-IPSC frequency from an average of $10.7 \pm 2.2 \mathrm{~Hz}$ to $4.6 \pm 0.2 \mathrm{~Hz}$. This effect reversed upon application of $5 \mu \mathrm{M}$ naloxone $(7.9 \pm$ $1.2 \mathrm{~Hz}$ ). However, in contrast to the actions of DPDPE on m-IPSCs, the s-IPSC amplitude distribution was shifted toward smaller events by the enkephalin (Fig. 7E). Application of naloxone $(5 \mu \mathrm{M})$ completely reversed the decrease in average s-IPSC amplitude (Fig. 7D). This effect on the s-IPSC amplitude distribution has been demonstrated previously for $\mu$ agonists, and was ascribed to a decrease in the number of larger action po- 
A

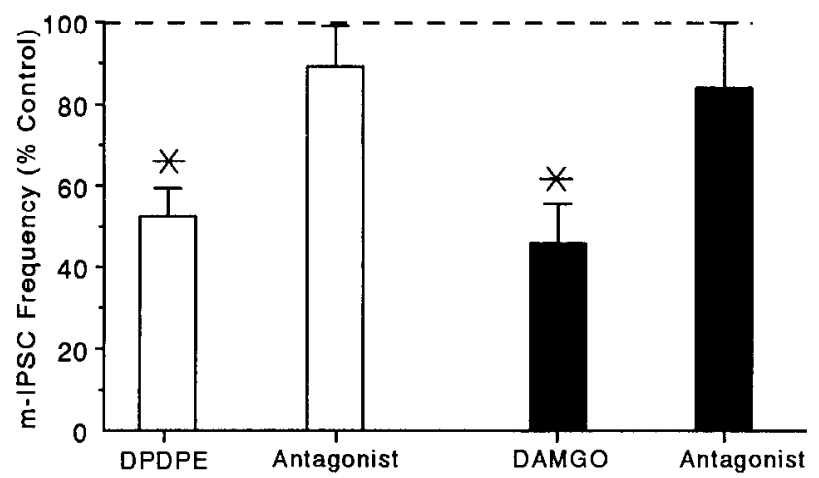

$\mathrm{B}$

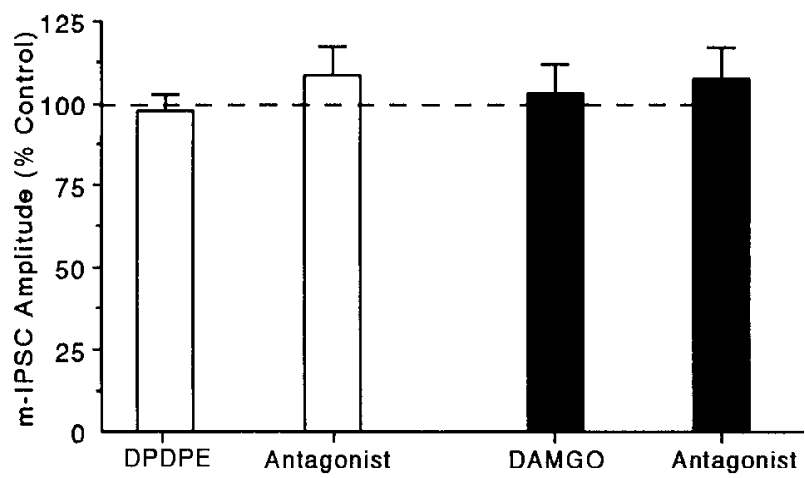

Figure 6. Summary of the effects of the selective $\delta$ agonist DPDPE ( $n$ $=16)$ and the selective $\mu$ agonist DAMGO $(n=8)$ on m-IPSC frequency $(A)$ and amplitude $(B)$ for all cells tested. The effects of DPDPE and DAMGO were reversed by the antagonists ICI $174,864(1 \mu \mathrm{M})$ or CTOP (1 $\mu \mathrm{M})$, respectively, or naloxone $(5 \mu \mathrm{M}){ }^{*}, p<0.01$ (paired $t$ test).

tential-dependent events (Cohen et al., 1992; Rekling, 1993). This effect of DPDPF on the average s-IPSC amplitude was modest when present (e.g., Fig. $7 E$ ), and reached significance (i.e., $p<0.01$, K-S test) in only two of the six neurons tested.

The application of 8 -Br-cAMP $(250 \mu \mathrm{M})$, by itself, had no significant effect on s-IPSC frequency or amplitude $(120 \pm 28 \%$ of control and $93 \pm 15 \%$ of control, respectively). Figure 8 shows the effects of the $\delta$ agonist DPDPE $(0.1 \mu \mathrm{M})$ and the $\mu$ agonist DAMGO $(0.1 \mu \mathrm{M})$ on s-IPSCs, in two different cells, following at least $30 \mathrm{~min}$ pretreatment with 8 -Br-cAMP $(250 \mu \mathrm{M})$. The $\delta$ opioid agonist DPDPE significantly decreased the s-IPSC frequency in this cell from $13.8 \mathrm{~Hz}$ to $4.4 \mathrm{~Hz}$, and this effect reversed $25 \mathrm{~min}$ after the drug application was terminated (wash, 13.1 Hz). DPDPE also caused a small but nonsignificant shift in the cumulative amplitude distribution of this cell (Fig. 8A3). Similar to the effects of DPDPE, the $\mu$ agonist DAMGO decreased the average s-IPSC frequency from $10.4 \mathrm{~Hz}$ to $5.3 \mathrm{~Hz}$, and this effect reversed upon washing (wash frequency, 11.9 $\mathrm{Hz}$ ). However, in contrast to the nonsignificant shift in the cumulative amplitude distribution by DPDPE, DAMGO caused a small but significant decrease in the average s-IPSC amplitude from $12.6 \pm 0.4 \mathrm{pA}$ to $9.6 \pm 0.4 \mathrm{pA}$ (Fig. $8 B 3$ ).

In an effort to ensure that this concentration of 8 - Br-cAMP was sufficient to alter cAMP-dependent processes, its effects were determined in a separate group of CA 1 pyramidal neurons using conventional intracellular recording with high-resistance pipettes (50-70 M $\Omega$ ) filled with potassium acetate $(2.5 \mathrm{M})$. Previous studies have shown that manipulations that increase cAMP concentrations, or the direct application of cAMP analogs such as 8-Br-cAMP, could reduce the afterhyperpolarization (AHP) that is observed in pyramidal neurons following a train of action potentials (Madison and Nicoll, 1986; Dunwiddie et al., 1992). However, another action of several cAMP analogs, including 8-Br-cAMP, is to activate adenosine $A_{1}$ receptors, which hyperpolarizes CA1 pyramidal neurons (Dunwiddie and Hoffer, 1980; Dunwiddie et al., 1992). Since this adenosine receptormediated hyperpolarization could interfere with AHP measurement, the effects of $250 \mu \mathrm{M} 8$-Br-cAMP on AHPs were detcrmincd following 10-15 min pretreatment with the adenosine receptor antagonist theophylline $(200 \mu \mathrm{M})$ (Lupica and Dunwiddie, 1990). Under these conditions it was found that 8 -Br-cAMP caused an average $58 \pm 6 \%$ reduction $(n=8 ; p<$ 0.05 , paired $t$ test) in the AHP measured following a train of action potentials, elicited by the injection of $200 \mathrm{msec}, 0.5 \mathrm{nA}$ depolarizing current pulses (Fig. 9A). These data indicate that this concentration of 8-Br-cAMP was sufficient to alter neuronal responses. A comparison of the effects of both the $\delta$ agonist DPDPE and the $\mu$ agonist DAMGO on s-IPSC frequency and amplitude under control conditions and following 8-Br-cAMP pretreatment is shown in Figure 9, $B$ and $C$. As this figure demonstrates, $250 \mu \mathrm{M} 8$-Br-cAMP did not alter the effects of the $\delta$ agonist or the $\mu$ agonist on s-IPSC average frequency or amplitude ( $p>0.05$, ANOVA).

\section{Discussion}

The results of the present study demonstrate that both $\delta$ and $\mu$ opioid receptors exist on inhibitory nerve terminals in the CAI region of the hippocampus. This conclusion is supported by the observation that enkephalin agonists that are highly selective for both the $\delta$ and the $\mu$ opioid receptor subtypes caused significant reductions in the frequency of $\mathrm{m}$-IPSCs without altering their amplitudes. The high level of selectivity of these agonists has been well documented in a variety of preparations (Mosberg et al., 1983; Cotton et al., 1985; Goldstein and Naidu, 1989). Although this was most apparent in the present study, where $\delta$ agonists were found to have no effects on evoked monosynaptic IPSCs but significantly inhibited $\mathrm{m}$-IPSCs. This differential effect of $\delta$ agonists is in contrast to the inhibition of both monosynaptic evoked IPSCs and m-IPSCs by the $\mu$ agonist. Clearly, if $\mu$ opioid receptors were activated by the $\delta$ agonists, then evoked IPSCs should have been reduced. In addition, the observation that the $\delta$ agonist DPDPE could reduce m-IPSC frequency following pretreatment with the $\mu$ antagonist CTOP (Fig. 4) further strengthens the argument that DPDPE did not activate $\mu$ opioid receptors. The distinction between $\delta$ and $\mu$ opioid agonist actions on evoked GABA release was first noted in this laboratory, and been has been subsequently confirmed by others (Lupica et al., 1992a; Capogna et al., 1993; Watson and Lanthorn, 1993). Several possible explanations for this absence of $\delta$ effects on evoked IPSCs remain to be evaluated. One possibility is that $\delta$ opioid receptors are simply not expressed on hippocampal inhibitory nerve terminals. However, this explanation seems unlikely given the present data. It is also possible that electrical stimulation activates only a subset of inhibitory terminals that do not express $\delta$ opioid receptors. This situation would be analogous to that described by Lambert and Wilson (1993), who demonstrated 
A
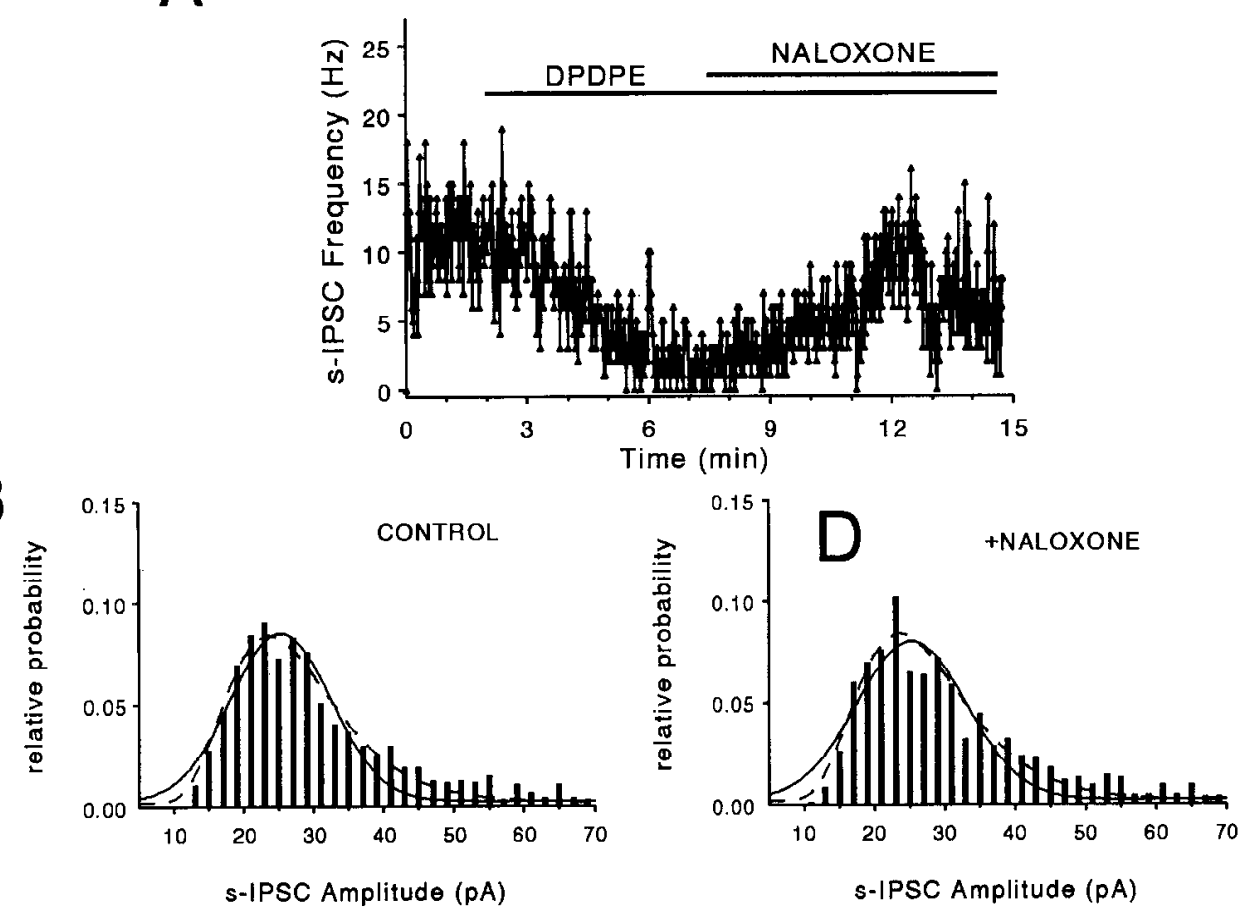

Figure 7. The $\delta$ enkephalin agonist DPDPE reduces the frequency and amplitude of spontaneous IPSCs recorded from a CAl pyramidal neuron in the absence of TTX. $A$, Effects of DPDPE $(0.2 \mu \mathrm{M})$ and naloxone $(5 \mu \mathrm{M})$ on the frequency of spontaneous action potential-dependent IPSC.s. Note the rapid reversal of the decreased s-IPSC frequency by naloxone. $B$, Control amplitude histogram of s-IPSCs ( $2 \mathrm{p} \Lambda$ bin width, $n=944$ events). The solid line is a Gaussian fit to the data set using the equation $y=a_{1} \exp \left(-0.5\left(x-a_{2}\right)\right.$ $\left.a_{3}\right)^{2}$ ), where $a_{1}$ is the height, $a_{2}$ is the center, $a_{3}$ is the standard deviation. The dashed line represents a log-normal tit to the same data using the same equation described in Figure 2. In each case $(B-D)$, the log-normal fit was better than the Gaussian (e.g., control data, Gaussian $r^{2}=0.90$ vs log-normal $r^{2}=0.97$ ). $C$, Amplitude distribution obtained during application of DPDPE $(n=1243$ events). $D$, Amplitude distribution obtained during concomitant application of DPDPE and naloxone $(n=1485$ events). $E$, Superimposed log-normal fits to the data obtained during control and DPDPE recording epochs. Note the significant shift (K-S statistic, $p<$ 0.0001 ) in the center of the distribution from the control value of $a_{2}=23.7 \mathrm{pA}$ to that obtained in DPDPE of $a_{2}=19.35$ pA. This reduction in s-IPSC amplitude was reversed by naloxone $\left(a_{2}=23.44\right.$ pA). The cross-hatched area reflects the relative change in the amplitude distribution, and the reduction of larger $s$-IPSCs in the DPDPE distribution. All data were obtained from the same cell. Voltage-clamp holding potential $=-70$ $\mathrm{mV}$.

that all inhibitory terminals examined expressed functional $\mu$ opioid receptors, but only a subset of these same terminals expressed $\mathrm{GABA}_{\mathrm{B}}$ receptors. However, if this is the case for $\delta$ opioid receptors, then the subset of interneurons that are activated by electrical stimulation must be distinct from those that spontaneously release GABA. This is because s-IPSC and $\mathrm{m}$-IPSC frequency was sensitive to the inhibitory effects of the $\delta$ agonists in every case examined. Another possibility is that $\delta$ receptor activation reduces evoked inhibitory input to pyramidal neurons at a remote location, and that the cable filtering properties of these cells reduce the contribution of this remote conductance to the summated whole-cell IPSC. This was addressed in the present study by recording evoked monosynaptic IPSCs from pyramidal neurons loaded with $130 \mathrm{~mm}$ chloride, in an attempt to enhance the detection of this remote conductance. However, the present results indicate that these responses were not affected by the $\delta$ agonists. While this investigation leaves unresolved this difference between $\delta$ and $\mu$ agonist effects on evoked IPSCs in this preparation, it is noteworthy that $\delta$ agonists (including DPDPE and Delt-II) have been shown to inhibit evoked IPSPs recorded from neurons in the rat anterior cingulate cortex, lat- eral amygdala, striatum, nucleus accumbens, and dentate gyrus, suggesting that the absence of $\delta$ actions on evoked IPSCs in the $\mathrm{CA} 1$ region of the hippocampus may be unique to this structure (Jiang and North, 1992; Yuan et al., 1992; Piguet and North, 1993; Sugita and North, 1993; Tanaka and North, 1994).

Another novel finding of this study was that $\delta$ agonists, like $\mu$ or nonselective opioid agonists, can alter s-IPSC amplitude distributions (Cohen et al., 1992; Rekling, 1993). In the present study, and the investigation by Cohen et al. (1992), this phenomenon was observed only when IPSCs were recorded in the absence of TTX. The enkephalin-induced decrease in s-IPSC amplitude seen in these previous studies and in the present investigation likely reflects the loss of larger action potentialdependent IPSCs following the hyperpolarization of GABAergic interneurons (Cohen et al., 1992). Thus, the present data provide the first evidence, albeit indirect, for the $\delta$ opioid-mediated hyperpolarization of hippocampal interneurons. Previously, this hyperpolarizing action has been demonstrated only for $\mu$ or nonselective opioid agonists (Madison and Nicoll, 1988; Wimpey and Chavkin, 1991). Given the present results, it can be concluded that $\delta$ opioid receptors probably reduce GABA release 

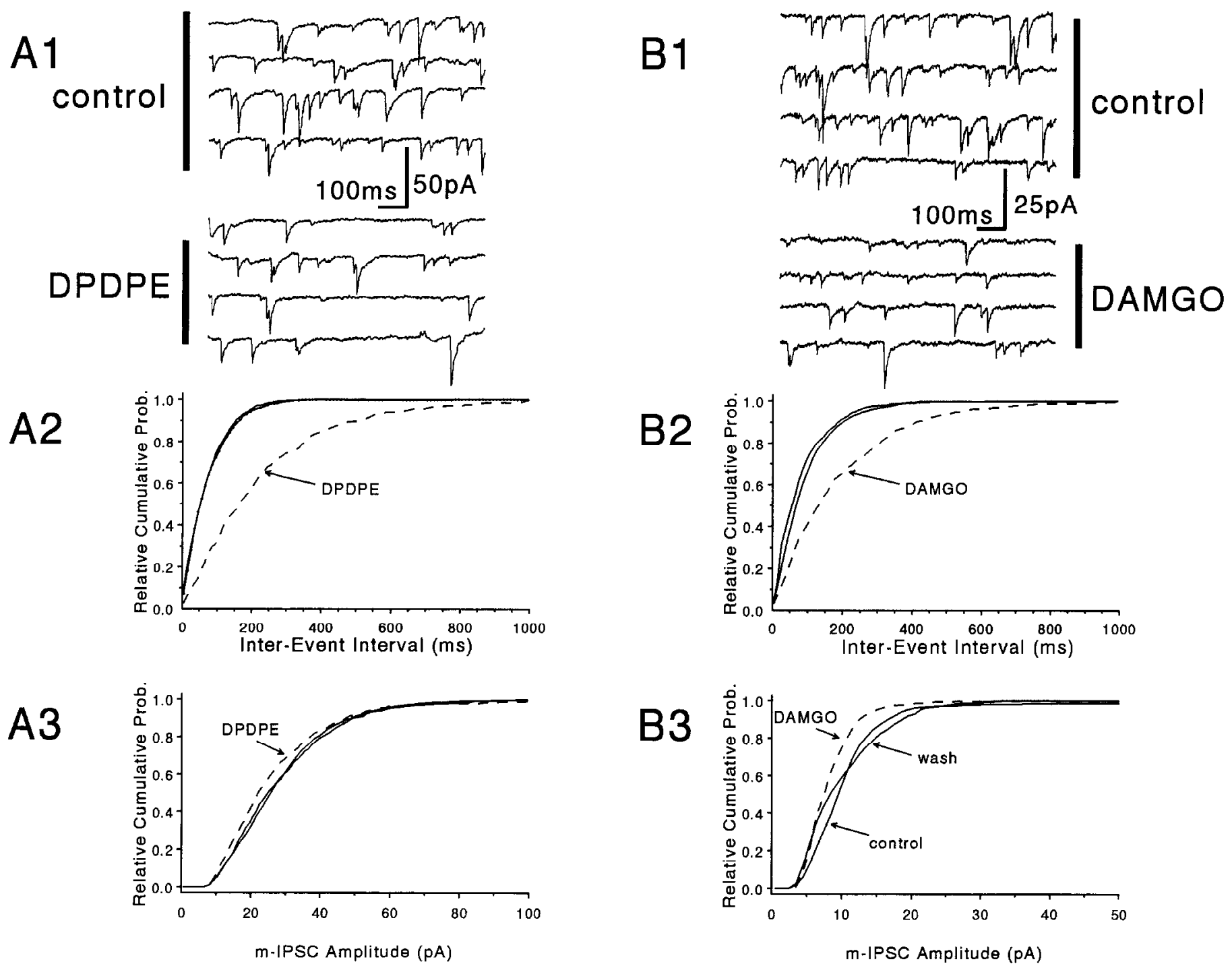

Figure 8. Pretreatment with the cAMP analog 8-Br-cAMP $(250 \mu \mathrm{M})$ does not alter the effect of $\delta$ or $\mu$ receptor activation on s-IPSCs. A1, Effects of the selective $\delta$ opioid receptor agonist DPDPE $(0.1 \mu \mathrm{M})$ on s-IPSCs during a 30 min pretreatment with 8-Br-cAMP. Each sweep is 1 sec in duration. A2, Effect of DPDPE on cumulative s-IPSC interevent interval distributions. Shown are curves obtained during control, DPDPE (dashed line), and washout epochs. The increase in the average interval between successive s-IPSCs in this cell was statistically significant (K-S statistic, $p$ $<0.0001$; control $=72.7 \pm 2.0 \mathrm{msec}, n=948$ events; DPDPE $=226.1 \pm 9.2 \mathrm{msec}, n=437$ events; wash $=76.3 \pm 0.4 \mathrm{msec}, n=1059$ events). $A 3$, Effects of DPDPE on cumulative s-IPSC amplitude distribution (dashed line). The effect of DPDPE on the s-IPSC amplitude distribution was not statistically significant (K-S statistic, $p>0.01$ ). $B$, Effects of the $\mu$ agonist DAMGO on s-IPSCs during a $60 \mathrm{~min} 8$-Br-cAMP pretreatment. Note that DAMGO $(0.1 \mu \mathrm{M})$ caused a prominent change in the cumulative interevent interval distribution $(B 2$, dashed line; mean interval $=188.5$ $\pm 7.1 \mathrm{msec}, n=630$ events) when compared to control $(95.9 \pm 2.4 \mathrm{msec}, n=1236$ events $)$ and washout $(83.8 \pm 2.6 \mathrm{msec}, n=1011$ events $)$ intervals $(p<0.0001, \mathrm{~K}-\mathrm{S}$ test). Similarly, DAMGú significantly $(p<0.0001, \mathrm{~K}-\mathrm{S}$ test) altered the amplitude of the s-IPSCs, as demonstrated by the shift in the cumulative amplitude distributions $(B 3)$.

through at least two distinct actions: the first, a direct effect at GABAergic nerve terminals, and the second, a more indirect action, following somatic hyperpolarization (Madison and Nicoll, 1988; Wimpey and Chavkin, 1991; Capogna et al., 1993). It should be noted that this interneuron hyperpolarization is probably not involved in the reduction of m-IPSC frequency, since the application of the $\mathrm{GABA}_{\mathrm{B}}$ receptor agonist baclofen, which is also known to hyperpolarize interneurons, does not alter m-IPSC frequency (Cohen et al., 1992; Scanziani et al., 1992). More generally, these data indicate that somatic hyperpolarization, by itself, may not accurately predict the level of inhibition of neurotransmitter release. Indeed, as in the case of baclofen or opioids acting upon GABAergic neurons in the hippocampus, the two actions can be dissociated.
The mechanism by which opioids inhibit GABA release in the hippocampus is unknown. Two potential candidates that have been investigated are the activation of a $\mathrm{K}^{+}$conductance and the inhibition of voltage-dependent $\mathrm{Ca}^{2+}$ channels (Werz and MacDonald, 1982; Williams et al., 1982; Hescheler et al., 1987; North ct al., 1987, 1988). Opioids can activate at least two independent $\mathrm{K}^{+}$conductances in hippocampal interneurons. One conductance is inwardly rectifying, and blocked by channel blockers such as barium and cesium. The second $\mathrm{K}^{+}$ conductance is voltage dependent, and its activation can be blocked by 8-Br-cAMP (Wimpey and Chavkin, 1991, 1992). The present study argues against the involvement of the latter $\mathrm{K}^{+}$channel in the modulation of s-IPSCs in the hippocampus, and at least two additional studies argue against the involvement 
of the former conductance in the opioid modulation of m-IPSC.s. One of these studies has shown that reduced extracellular $\mathrm{K}^{+}$ concentrations had no effect on the ability of the $\mu$ agonist DAMGO to inhibit m-IPSC frequency (Rekling, 1993). The second study, as discussed above, has shown that the hyperpolarization of interneurons following the activation of the inwardly rectifying $\mathrm{K}^{+}$channel by baclofen has no effect on m-IPSCs (Cohen ct al., 1992). The evidence for $\mathrm{Ca}^{2+}$ channel involvement in the opioid modulation of m-IPSCs is similarly weak. Thus, despite the fact that opioids have been shown to inhibit somatic $\mathrm{Ca}^{2+}$ currents in a variety of preparations, $\mathrm{Ca}^{2+}$ channel blockade with cadmium or a reduction in the extracellular $\mathrm{Ca}^{2+}$ concentration has no effect on m-IPSC frequency or the ability of $\mu$ enkephalins to inhibit m-IPSC frequency (Otis et al., 1991; Scanziani et al., 1992; Rekling, 1993). It would seem, therefore, that opioids may alter action potential-independent GABA release from hippocampal interneurons via the disruption of a critical event in the secretion process that does not involve $\mathrm{Ca}^{2+}$ flux across the nerve terminal membrane.

One of the goals of the present experiments was to assess the potential role of cAMP-dependent processes in the opioid inhibition of spontaneous GABA release in the hippocampus. The rationale for these experiments was derived from the observation that opioids inhibit adenylate cyclase in a variety of neural preparations (Van Vliet et al., 1990; Fleming et al., 1992; Schoffelmeer et al., 1992), and that this can result in the inhibition of cAMP-dependent phosphorylation of neural proteins (Guitart and Nestler, 1989; Fleming et al., 1992). Other studies have demonstrated that the inhibition of adenylate cyclase can be mediated by both $\delta$ and $\mu$ receptors (Childers, 1993; Buzas et al., 1994). An additional reason for these cxpcriments was derived from the recent demonstration that $\mu$ opioids could activate a voltage-dependent $\mathrm{K}^{+}$channel, located in hippocampal interneurons, that was blocked by 8 -Br-cAMP (Wimpey and Chavkin, 1991, 1992). Thus, it was hypothesized in the present study that if a decrease in cAMP accumulation by opioids was associated with the inhibition of GABA release, then the application of a cAMP analog should, by itself, increase the release of GABA or reverse the effects of $\delta$ and $\mu$ opioids. However, it was shown that, alone, 8-Br-cAMP had no effect on s-IPSCs, nor did it alter the inhibitory modulation of these currents by $\delta$ or $\mu$ receptor activation. This suggests that the only physiological response to opioids that has been linked to altered CAMP levels, the voltage-dependent $\mathrm{K}^{+}$conductance, is not responsible for the opioid modulation of spontaneous GABA release in the hippocampus. Some recent biochemical investigations have also failcd to link the inhibition of adenylate cyclase to the opioid inhibition of neurotransmitter release (Schoffelmeer et al., 1986; De Vries et al., 1990; Johnson, 1990; Heijna et al., 1992). It may be relevant that this 8 -Br-cAMP-sensitive current has been reported to be active only when interneurons were substantially depolarized from rest (Wimpey and Chavkin, 1991, 1992). Thus, it was possible that the inability to demonstrate an interaction between $8-\mathrm{Br}-\mathrm{c} A \mathrm{MP}$ and $\delta$ or $\mu$ opioid modulation of s-IPSCs might be because this voltage-dependent conductance was not active under the present conditions. The evaluation of this hypothesis will require further experimentation.

In conclusion, the results of the present study demonstrate that both $\delta$ and $\mu$ opioid receptors exist on the terminals of GABA-containing interneurons in the $\mathrm{CAl}$ region of the rat hippocampus, and suggest that the modulation of spontaneous GABA release by each of these opioid receptor subtypes occurs
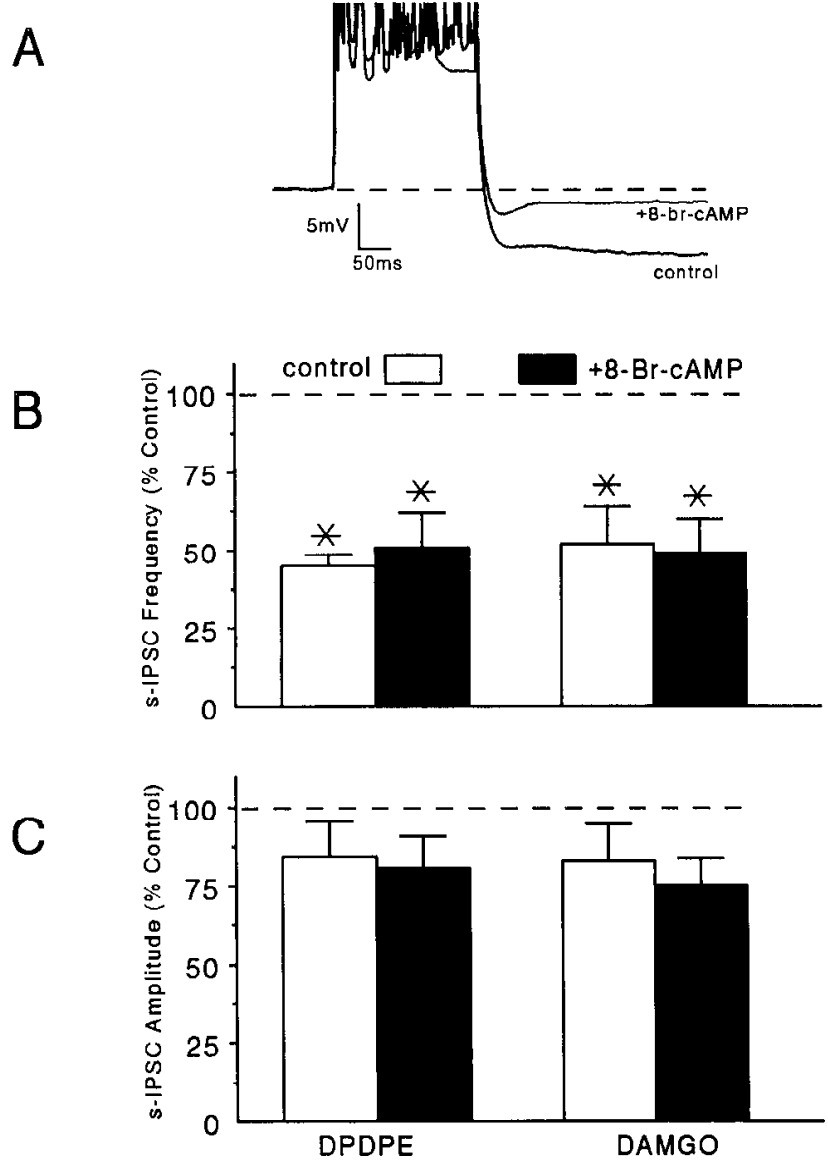

Figure 9. Summary of 8-bromo-cAMP $(8-B r-c A M P)$ effects on pyramidal neuron responses. $A$, Effects of 8-Br-cAMP on AHPs recorded from a $\mathrm{CAl}$ pyramidal neuron that was pretreated with the adenosine receptor antagonist theophylline $(200 \mu \mathrm{M})$. Action potentials were elicited by passing a $200 \mathrm{msec}, 0.5 \mathrm{nA}$ pulse through a conventional $\mathrm{K}^{+}-$ acetate-filled intracellular electrode. Note the prominent decrease in the AHP during application of $250 \mu \mathrm{M} 8$-Br-cAMP. The same action of 8-Br-cAMP was seen in eight of eight pyramidal neurons. $B$, Effects of the $\delta$ agonist DPDPE and the $\mu$ agonist DAMGO on s-IPSC frequency in the absence ( $n=6$ and $n=5$, respectively) and following at least 30 min pretreatment with $250 \mu \mathrm{M} 8$-Br-cAMP $(n=7$ and $n=5$, respectively). $C$, Effects of DPDPE and DAMGO on s-IPSC amplitude. Note the small, nonsignificant decrease in the average s-IPSC amplitude with both agonists. Significant decreases in average s-IPSC amplitudes were observed in some but not all cases (e.g., Figs. 7, 8). Note also that the cAMP analog had no significant effect on the modulation of s-IPSC frequency or amplitude by DPDPE or DAMGO. ${ }^{*}$, significance $(p<$ 0.05 ) when compared to $100 \%$ of control (ANOVA).

independently of cAMP-dependent mechanisms. However, perhaps morc importantly, this study also demonstrates that presynaptic $\delta$ opioid receptors differentially modulate spontaneous and evoked neurotransmitter release. Thus, in contrast to the idea that the mechanisms underlying the presynaptic inhibition of evoked and spontaneous neurotransmitter release are the same (Capogna et al., 1993; Thompson et al., 1993), the present dissociation of $\delta$ agonist actions suggests that the mechanisms supporting the inhibilion of spontaneous and evoked neurotransmitter release may be different.

\section{References}

Bostock E, Dingledine R, Xu G, Chang KJ (1984) Mu opioid receptors participate in the excitatory effects of opioids in the hippocampal slice. J Pharmacol Exp Ther 231:512-517. 
Buzas B, Izenwasser S, Portoghese PS, Cox BM (1994) Evidence for delta opioid receptor subtypes regulating adenylyl cyclase activity in rat brain. Life Sci 54:PL101-PL106.

Capogna M, Gahwiler BII, Thompson SM (1993) Mcchanism of $\mu$-opioid receptor-mediated presynaptic inhibition in the rat hippocampus in vitro. J Physiol (Lond) 470:539-558.

Childers SR (1993) Opioid receptor-coupled second messenger systems. In: Handbook of experimental pharmacology: opioids I (Herz A, ed), pp 189-216. New York: Springer.

Cohen GA, Doze VA, Madison DV (1992) Opioid inhibition of GABA release from presynaptic terminals of rat hippocampal interneurons. Neuron 9:325-335.

Cotton R, Kosterlitz HW, Paterson SJ, Rance MJ, Traynor JR (1985) The use of $\left[{ }^{3} \mathrm{H}\right]-\left[\mathrm{D}-\mathrm{Pen}^{2}, \mathrm{D}-\mathrm{Pen}^{5}\right]$ enkephalin as a highly selective ligand for the delta-binding site. Br J Pharmacol 84:927-932.

Crain BJ, Chang KJ, McNamara JO (1986) Quantitative autoradiographic analysis of $\mathrm{mu}$ and delta opioid binding sites in the rat hippocampal formation. J Comp Neurol 246:170-180.

Davies SN, Collingridge GL (1989) Role of excitatory amino acid receptors in synaptic transmission in area $\mathrm{CAl}$ of rat hippocampus. Proc R Soc Lond [Biol] 236:373-384.

De Vries TJ, Schoffelmeer AN, Delay-Goyet P, Roques BP, Mulder AH (1989) Selective effects of [D-Ser2(O-t-butyl),Leu5]enkephalyl-Thr6 and [D-Ser2( $O$ - $t$-butyl),Leu5]enkephalyl-Thr6 ( $O$ - $t$-butyl), two new enkephalin analogues, on neurotransmitter release and adenylate cyclase in rat brain slices. Eur J Pharmacol 170:137-143.

De Vries TJ, Hogenboom F, Mulder AH, Schoffelmeer AN (1990) Ontogeny of mu-, delta- and kappa-opioid receptors mediating inhibition of neurotransmitter release and adenylate cyclase activity in rat brain. Brain Res Dev Brain Res 54:63-69.

Dingledine R (1981) Possible mechanisms of enkephalin action on hippocampal CA1 pyramidal ncurons. J Neurosci 1:1022-1035.

Dunwiddie TV, Hoffer BJ (1980) Adenine nucleotides and synaptic transmission in the in vitro rat hippocampus. Br J Pharmacol 69:5968.

Dunwiddie TV, Mueller AL, Palmer MR, Stewart JM, Hoffer BJ (1980) Electrophysiological interactions of enkephalins with neuronal circuitry in the rat hippocampus. I. Effects on pyramidal cell activity. Brain Res 184:311-330.

Dunwiddie TV, Taylor M, Heginbotham LR, Proctor WR (1992) Longterm increases in excitability in the CA1 region of rat hippocampus induced by $\beta$-adrenergic stimulation: possible mediation by cAMP. J Neurosci 12:506-517.

Erspamer V, Melchiorri P, Falconieri-Erspamer G, Negri L, Corsi R, Severini C, Barra D, Simmaco M, Kreil G (1989) Deltorphins: a family of naturally occurring peptides with high affinity and selectivity for delta opioid binding sites. Proc Natl Acad Sci USA 86:5188-5192.

Fatt P, Katz B (1952) Spontaneous subthreshold activity at motor nerve endings. J Physiol (Lond) 117:109-128.

Fleming LM, Ponjee G, Childers SR (1992) Inhibition of protein phosphorylation by opioid-inhibited adenylyl cyclase in rat brain membranes. J Pharmacol Exp Ther 260:1416-1424.

Goldstein A Naidu A (1989) Multiple opioid receptors: ligand selectivity profiles and binding site signatures. Mol Pharmacol 36:265272.

Guitart X, Nestler EJ (1989) Identification of morphine- and cyclic AMP-regulated phosphoproteins (MARPPs) in the locus coeruleus and other regions of rat brain: regulation by acute and chronic morphine. J Neurosci 9:4371-4387.

Hcijna MH, Hogenboom F, Portoghese PS, Mulder AH, Schoffelmeer ANM (1989) Mu and delta-opioid receptor-mediated inhibition of adenylate cyclase activity stimulated by released endogenous dopamine in rat neostriatal slices; demonstration of potent delta-agonist activity of bremazocine. J Pharmacol Exp Ther 249:864-868

Heijna MH, Hogenboom F, Mulder AH, Schoffelmeer AN (1992) Opioid receptor-mediated inhibition of ${ }^{3} \mathrm{H}$-dopamine and ${ }^{14} \mathrm{C}$-acetylcholine release from rat nucleus accumbens slices. A study on the possible involvement of $\mathrm{K}^{+}$channels and adenylate cyclase. Naunyn Schmiedebergs Arch Pharmacol 345:627-632.

Herkenham M, McLean S (1988) The anatomical relationship of opioid peptides and opiate receptors in the hippocampi of four rodent species. In: NIDA research monograph series 82, Opioids in the hippocampus (McGinty JF, Friedman DP, eds), pp 33-47. Rockville, MD: U.S. Department of Health and Human Services.

Hescheler J, Rosenthal W, Trautwein W, Schultz G (1987) The GTP- binding protein, Go, regulates neuronal calcium channels. Nature 325: $445-447$.

Jiang ZG, North RA (1992) Pre- and postsynaptic inhibition by opioids in rat striatum. $J$ Neurosci 12:356-361

Johnson SM (1990) Opioid inhibition of cholinergic transmission in the guinea-pig ileum is independent of intracellular cyclic AMP. Eur J Pharmacol 180:331-338.

Johnson SW, North RA (1992) Opioids excite dopamine neurons by hyperpolarization of local interneurons. J Neurosci 12:483-488

Kramer TH, Davis P, Hruby VJ, Burks TF, Porreca F (1993) In vitro potency, affinity and agonist efficacy of highly selective delta opioid ligands. J Pharmacol Exp Ther 266:577-584.

Lambert NA, Wilson WA (1993) Heterogeneity in presynaptic regulation of GABA release from hippocampal inhibitory neurons. Neuron 11:1057-1067.

Lambert NA, Harrison NL, Teyler TJ (1991) Evidence for $\mu$ opiate receptors on inhibitory terminals in area $\mathrm{CAl}$ of rat hippocampus. Neurosci Lett 124:101-104.

Lee HK, Dunwiddie TV, Hoffer BJ (1980) Electrophysiological interactions of enkephalins with neuronal circuitry in the rat hippocampus. II. Effects on interneuron excitability. Brain Res 184:331342.

Lupica CR, Dunwiddie TV (1990) Release of endogenous adenosine does not mediate electrophysiological responses to morphine in the hippocampus in vitro. Neuropharmacology 29:1131-1139.

Lupica CR, Dunwiddie TV (1991) Differential effects of mu- and deltareceptor selective opioid agonists on feedforward and feedback GABAcrgic inhibition in hippocampal brain slices. Synapse 8:237-248.

Lupica CR, Proctor WR, Dunwiddie TV (1992a) Dissociation of $\mu$ and $\delta$ opioid receptor-mediated reductions in evoked and spontaneous synaptic inhibition in the rat hippocampus in vitro. Brain Res 593 226-238.

Lupica CR, Proctor WR, Dunwiddie TV (1992b) Presynaptic inhibition of excitatory synaptic transmission by adenosine in rat hippocampus: analysis of unitary EPSP variance measured by whole-cell recordings. J Neurosci 12:3753-3764.

Madison DV, Nicoll RA (1986) Cyclic adenosine 3',5'-monophosphate mediates $\beta$-receptor actions of noradrenaline in rat hippocampal pyramidal cells. J Physiol (Lond) 372:245-259.

Madison DV, Nicoll RA (1988) Enkephalin hyperpolarizes interneurones in the rat hippocampus. J Physiol (Lond) 398:123-130.

Mosberg HI, Hurst R, Hruby VJ, Gee K, Yamamura HI, Galligan JJ, Burks TF (1983) Bis-penicillamine enkephalins possess highly improved specificity toward delta opioid receptors. Proc Natl Acad Sci USA 80:5871-5874.

Nicoll RA, Algcr BE, Jahr CE (1980) Enkephalin blocks inhibitory pathways in the vertebrate CNS. Nature 287:22-25.

North RA, Surprenant A, Tatsumi H (1988) Potassium conductance increase and calcium conductance decrease both evoked by alpha 2 adrenaline and delta opioid receptor agonists in the same guinea pig submucous plexus neurones. J Physiol (Lond) 406:179P.

North RA, Williams JT, Surprenant A, Christie MJ (1987) Mu and delta receptors belong to a family of receptors that are coupled to potassium channels. Proc Natl Acad Sci USA 84:5487-5491.

Otis TS, Staley KJ, Mody I (1991) Perpetual inhibitory activity in mammalian brain slices generated by spontaneous GABA release. Brain Res 545:142-150.

Pang K, Rose GM (1989) Differential effects of methionine ${ }^{5}$-enkephalin on hippocampal pyramidal cells and interneurons. Neuropharmacology 28:1175-1181.

Piguet P, North RA (1993) Opioid actions at mu and delta receptors in the rat dentate gyrus in vitro. J Pharmacol Exp Ther 266:11391149.

Rekling JC (1993) Effects of met-enkephalin on GABAergic spontaneous miniature IPSPs in organotypic slice cultures of the rat hippocampus. J Neurosci 13:1954-1964.

Scanziani M, Capogna M, Gahwiler BH, Thompson SM (1992) Presynaptic inhibition of miniature excitatory synaptic currents by baclofen and adenosine in the hippocampus. Neuron 9:919-927.

Schoffelmeer AN, Wierenga EA, Mulder AH (1986) Role of adenylate cyclase in presynaptic $\alpha_{2}$-adrenoreceptor- and $\mu$-opioid receptor-mediated inhibition of $\left[{ }^{3} \mathrm{H}\right]$-noradrenaline release from rat brain cortex slices. J Neurochem 46:1711-1717.

Schoffelmeer $\Lambda$ NM, De Vries TJ, Hogenboom F, Hruby VJ, Portoghese PS, Mulder AH (1992) Opioid receptor antagonists discriminate 
between presynaptic mu and delta receptors and the adenylate cyclase coupled opioid receptor complex in the brain. J Pharmacol Exp Ther 263:20-24.

Sharif NA, Hughes J (1989) Discrete mapping of brain mu and delta opioid receptors using selective peptides: quantitative autoradiography, species differences and comparison with kappa receptors. Peptides 10:499-522.

Sugita S, North RA (1993) Opioid actions on neurons of rat lateral amygdala in vitro. Brain Res 612:151-155.

Tanaka E, North RA (1994) Opioid actions on rat anterior cingulate cortex neurons in vitro. J Neurosci 14:1106-1113.

Thompson SM, Capogna M, Scanziani M (1993) Presynaptic inhibition in the hippocampus. Trends Neurosci 16:222-227.

Van Der Kloot W (1991) The regulation of quantal size. Prog Neurobiol 36:93-130.

Van Vliet BJ, Mulder AH, Schoffelmeer ANM (1990) Mu-opioid receptors mediate the inhibitory effect of opioids on dopamine-sensitive adenylate cyclase in primary cultures of rat neostriatal neurons. J Neurochem 55:1274-1280.

Watson GB, Lanthorn TH (1993) Electrophysiological actions of delta opioids in CAl of the rat hippocampal slice are mediated by one delta receptor subtype. Brain Res 601:129-135.

Werz MA, MacDonald RL (1982) Heterogeneous sensitivity of cultured dorsal root ganglion neurones to opioid peptides selective for mu- and delta-opiate receptors. Nature 299:730-733.

Williams JT, Egan TM, North RA (1982) Enkephalin opens potassium channels on mammalian central neurones. Nature 299:74-77.

Wimpey TL, Chavkin C (1991) Opioids activate both an inward rectifier and a novel voltage-gated potassium conductance in the hippocampal formation. Neuron 6:281-289.

Wimpey TL, Chavkin C (1992) 8-Bromo-cAMP blocks opioid activation of a voltage-gated potassium current in isolated hippocampal neurons. Neurosci Lett 137:137-140.

Yuan X, Madamba S, Siggins GR (1992) Opioid peptides reduce synaptic transmission in the nucleus accumbens. Neurosci Lett I34 223-228.

Zieglgansberger W, French ED, Siggins GR, Bloom FE (1979) Opioid peptides may excite hippocampal pyramidal neurons inhibiting adjacent inhibitory interneurons. Science 205:415-417. 